\title{
Assessing the Causes of Late Pleistocene Extinctions on the Continents
}

\author{
Anthony D. Barnosky, ${ }^{1 *}$ Paul L. Koch, ${ }^{2}$ Robert S. Feranec, ${ }^{1}$ Scott L. Wing, ${ }^{3}$ Alan B. Shabel ${ }^{1}$
}

One of the great debates about extinction is whether humans or climatic change caused the demise of the Pleistocene megafauna. Evidence from paleontology, climatology, archaeology, and ecology now supports the idea that humans contributed to extinction on some continents, but human hunting was not solely responsible for the pattern of extinction everywhere. Instead, evidence suggests that the intersection of human impacts with pronounced climatic change drove the precise timing and geography of extinction in the Northern Hemisphere. The story from the Southern Hemisphere is still unfolding. New evidence from Australia supports the view that humans helped cause extinctions there, but the correlation with climate is weak or contested. Firmer chronologies, more realistic ecological models, and regional paleoecological insights still are needed to understand details of the worldwide extinction pattern and the population dynamics of the species involved.

$\mathbf{F}$ ifty thousand years ago, continents were populated with more than 150 genera of megafauna (animals $>44 \mathrm{~kg}$ ) (1-4). By 10,000 years ago, at least 97 of those genera were gone (Fig. 1, Table 1, and table S1) (5). Prevailing explanations include human impacts $(1,2,6-8)$, environmental changes $(1,2,9-11)$, and a combination of both $(1,3,4,12-14)$. If humans caused the extinctions, it will profoundly influence our thinking about what is "natural" (15), how ecosystems respond to different scales and kinds of environmental change (16), how long extinctions take (17), and conservation of species and ecosystems $(2,18,19)$.

Anthropogenic extinction models, including overkill (20), blitzkrieg (rapid overkill) (21), and sitzkrieg (fire, habitat fragmentation, and the introduction of exotic species and diseases) (6), have been considered plausible because large animals were preferentially affected $(1,2,5,22,23)$. Species with low reproductive rates, with which large body size correlates, were hit hardest $(24,25)$. Almost all of the slow-breeding survivors in Australia, Eurasia, the Americas, and Madagascar are nocturnal, arboreal, alpine, and/or deep-forest dwellers, which is consistent with overkill models of extinction but hard to explain by environmental change

${ }^{1}$ Department of Integrative Biology and Museums of Paleontology and Vertebrate Zoology, University of California, Berkeley, CA 94720, USA. ${ }^{2}$ Department of Earth Sciences, University of California, Santa Cruz, CA 95064, USA. ${ }^{3}$ Department of Paleobiology, National Museum of Natural History, Smithsonian Institution, Washington, DC 20560, USA.

*To whom correspondence should be addressed. E-mail: barnosky@socrates.berkeley.edu alone (24). Survival of large, open-country, slow-breeding animals in Africa is an exception to this pattern that must factor into extinction explanations.

On islands, humans cause extinctions through multiple, synergistic effects, including predation and sitzkrieg $(1,2,6,26)$. Only rarely have island megafauna been demonstrated to go extinct because of environmental change without human involvement (27-29). Incontrovertible impacts of humans on islands have been cited as a potent argument that prehistoric humans also caused extinctions on continents $(1,2,6)$, but extrapolation of extinction mechanisms from islands to continents is often disputed $(4,26)$. Here, we focus on the continents, where causes of extinction remain controversial $(8,19,30-32)$.

The perspective from Eurasia and Africa has been that humans exerted at most a minor influence on Pleistocene extinctions, whereas in Australia, North America, and South America, a primary role for humans has been strongly argued (1-3). How consistent with that perspective is recent evidence from simulations, chronology, archaeology, paleontology, climatology, and ecology?

\section{Simulations}

Most simulations (table S2) (5) treat prey as a single species with life history parameters [initial biomass, population growth rate $(r)$, and carrying capacity $(K)$ ] that are varied, either to simulate effects on particular species [such as mammoth $(33)$ or moa $(34,35)$ ] or to understand values that render prey vulnerable to extinction $(20,21,36,37)$. Either human population dynamics are modeled with parameters that respond to prey population size $(20,21)$, or human population densities are varied independently in sensitivity tests (34-37). Hunting efficiency is varied too.

Results differ depending on the input parameters (5). Overkill occurs consistently in single-prey simulations with coupled human-prey population dynamics, but stability analyses suggest this may be a mathematically inevitable outcome (38). Simulations with uncoupled human and prey population dynamics produced blitzkrieg for New Zealand moas $(34,35)$, but other simulations counterintuitively found that overkill was less likely for large, slow-breeding prey $(36,37)$, perhaps because the models feature low human population densities and assume hunting efficiency drops as prey become rare.

Simulations of humans foraging on multiple prey (as opposed to one prey species) yield the crucial idea that overkill of slowbreeding prey is more likely when hunter populations become large, because hunters are subsidized by eating rapidly breeding prey or gathered foods when preferred slow-breeding prey becomes scarce $(38,39)$. The most comprehensive simulation $(8)$ involves predation by North American immigrants on 41 species of large animals and a single, undifferentiated secondary resource (plants and small game). Assuming that hunters nonselectively took prey as it was encountered, overkill resulted for a range of hunting efficiencies, geography of invasion, and competitive interactions (5). The best model correctly predicted the fate of 34 of 41 species, with final human population densities of $\sim 28$ people per $100 \mathrm{~km}^{2}$ receiving $\sim 30 \%$ of their calories from large animals. The median time to extinction was 895 years (40). The rules of this simulation did not allow prey species to disperse outside geographic ranges estimated from fossil data (41), whereas humans were allowed to disperse anywhere. Such assumptions are consistent with climatic or other environmental limits to the ranges of large mammals and show how climate could modulate an extinction driven primarily by human hunting.

Logical next steps would be to apply sensitivity tests to assumptions about geographic ranges, carrying capacity, and rules of 
dispersal and to allow realistic, selective foraging by humans. Assumptions about prey naiveté influence outcomes of single-prey simulations $(4,37)$ and need to be explored for multipleprey simulations [e.g., $(8,39)]$. It will be important to learn if realistic models can simulate the survival of megafauna in Africa or the magnitude of extinction in Australia, a continent where some question whether human populations were ever large or technologically sophisticated enough to drive overkill (4).

\section{Chronology}

Recent work has confirmed two salient points for northern high- and mid-latitudes:

1) In northern Europe, Siberia, and Alaska, extinction occurred in two pulses coincident with climatic change (Fig. 2C), with the loss of warm-adapted animals from 45 to 20 thousand radiocarbon years before present (ky RCBP) and cold-adapted animals from 12 to 9 ky RCBP (5). The pulsed demise of the megafauna in Eurasia also coincides with first the spread and then increases in population sizes of Homo sapiens sapiens (42), who had a more diverse suite of tools and broader diets $(14,43)$ than the pre-sapiens hominins. Presapiens hominins hunted megafauna in Europe for at least 400,000 years (44) without inducing extinctions, but may have lived at densities too low to have a pronounced impact on prey populations (43). Some species survived in northern Eurasia into the midHolocene (5); these late survivors were in areas where human populations were never large.

2) In central North America, the arrival of Clovis-style hunters, extinction of megafauna, and marked climatic change all cluster between 11.5 and 10 ky RCBP $(31,45)$. Published accounts suggest that at least 15 species became extinct near the start of or during the Younger Dryas climate event, perhaps within the short "Clovis window" between 11.4 and $10.8 \mathrm{ky} \operatorname{RCBP}(19,31,46)$. A close correspondence of extinction with both human arrival and climatic change is well supported.

Thus, in mid-latitudes of the Northern Hemisphere, extinction was most pronounced where climatic change and new (North America) or potentially increased (Eurasia) human impacts hit simultaneously. In the far north, the geographically complex chronology of extinction suggests that an interplay between human impacts and climatic change governed extinction dynamics. For some species [such as mammoths $(29,47-49)$ and giant Irish deer (50)], Siberia and certain islands apparently offered refugia in regions that lacked large human populations. In other areas and for other species [such as horses and mammoths in mainland Alaska (11)], extinction occurred with climatic change even in the absence of significant human populations.

In the Southern Hemisphere, the story is still unfolding, with new information from
Australia playing a key role. Australia's main extinction pulse was earlier than in the Northern Hemisphere, came after humans arrived, and seems not to match any major regional or global climatic change. However, the chronology is much less secure than for Eurasia and North America. The most comprehensive Australian analyses indicate that of the 21 extinct genera of megafauna, 12 persisted to at least 80 ky BP, and at least 6 persisted to between 51 and $40 \mathrm{ky}$ BP $(7,37)$. Humans arrived somewhere between 71.5 and 44.2 ky BP $(5,37)$. Both human arrival and megafaunal extinction seem to predate regionally evident Late Glacial Maximum climatic change (7) (Fig. 2B). It is disputed whether megafauna lingered as recently as 28 ky BP in sites such as Cuddie Springs $(4,51,52)$ and whether ocean-based climatic records are reliable proxies for environmental change on the Australian continent $(4,5)$.

In South America, generally accepted dates place humans in coastal Chile and Patagonia at 12.9 to $12.5 \mathrm{ky}$ RCBP (53-55), and sites younger than 10 ky RCBP are common (56). The megafauna went extinct in the late Pleistocene, probably after humans arrived and as climate changed, but until more comprehensive analyses are undertaken, little else can be said with certainty.

Supporters of overkill have long argued that extinctions in Africa (5) and central Eurasia were milder (Fig. 1, Table 1, and table S1) because humans coevolved with megafauna there for hundreds of thousands of years, whereas they were an invasive species in the Americas and Australia. That would explain the magnitude of extinction in the Americas and Australia, but it offers no insights as to why any extinctions took place in Africa, or why Eurasia experienced a $36 \%$ loss of its megafauna. 
Solving those problems will require a better understanding of the extinction chronology, background extinction rates, timing and details of climatic change, and patterns of human population growth and resource use.

\section{Archaeology and Paleontology}

On all of the involved continents, archaeological remains and extinct megafauna have been found in association (5). Debate continues on two unresolved questions:

1) What constitutes evidence that humans hunted megafauna? In Africa and Eurasia, acceptable evidence includes cut marks and breakage of fossil bones. In contrast, cut marks and breakage alone are seldom regarded as strong evidence in North America $(57,58)$. New insights are possible by applying uniform criteria across continents to recognize kill sites, but such comparisons have not yet been done.

2) Are there too few kill sites to support overkill models? Until recently, it was not possible to determine if the number of kill sites (however one defines them) was consistent with a given overkill model, because we could not quantify the proportion of kill sites relative to all fossil occurrences of extinct taxa. With electronic databases $(41,57)$, estimating these proportions is now feasible for North America. Under certain assumptions (5), the data suggest that on that continent (i) kill sites are very frequent for mammoths; (ii) at least one taxon (Platygonus, the peccary) is found at fewer kill sites than expected; and (iii) most taxa are too rare in the fossil record

Table 1. Numbers of mammalian megafaunal genera affected by Pleistocene extinction. Numbers are based on our vetting of the primary literature (5), including but not restricted to (1-4) and (7). Column A gives the number of genera on a given continent that went extinct globally; column $B$, the number of extinct genera that survived on another continent; column $\mathrm{C}$, the number of Pleistocene genera on the continent that were still alive historically; and column D, the percent of megafaunal genera that went extinct on each continent (columns $\mathrm{A}+\mathrm{B}$ divided by columns $\mathrm{A}+\mathrm{B}+\mathrm{C}$ ).

\begin{tabular}{lrrrr} 
Continent & A & B & C & D \\
\hline Africa & 5 & 3 & 36 & 18 \\
Australia* & 14 & - & 2 & 88 \\
Eurasia $\dagger$ & 5 & 4 & 16 & 36 \\
North America & 28 & 5 & 13 & 72 \\
South America & 49 & 1 & 10 & 83
\end{tabular}

*Australia also has seven extinct (and no surviving) genera of megafaunal reptiles and birds. †Our use of "Eurasia" encompasses only northern Asia (part of the Palaearctic Region), because insufficient data exist to include southern Asia (the Oriental Region). to reliably judge their kill-site frequency (table S3).

\section{Climatic Change and Ecological Effects}

Climatic change is known to affect animals, often by triggering vegetation changes (5). The question is whether late Pleistocene climatic changes were unusual enough to trigger unusual ecological response. Three ecological models with general explanatory power have been applied to the Pleistocene extinctions debate: the proboscideansas-keystone species model $(2,5,59)$, coevolutionary disequilibrium $(5,10)$, and the mosaic-nutrient model $(5,60)$. One prediction of the keystone-species model is that proboscideans should be the first to disappear in the fossil record, but in Eurasia $(47,48,61)$, Alaska (11), and probably central North America $(31,62,63)$, they were among the last to go. The co-evolutionary disequilibrium and mosaic-nutrient models require that the changes in climate and ecosystem structure at the time of extinction were unusual relative to earlier conditions in the Pleistocene. This is underscored by recent work demonstrating that megafaunal extinction did not characterize earlier glacial-interglacial transitions in Europe $(3,14)$, Australia $(5,64)$, or North America $(5,65,66)$.

Paleoclimate records do not support a unique late Pleistocene transition. Globalscale oxygen-isotope records indicate that the most recent deglaciation was neither more rapid nor of greater magnitude than other shifts in the past 700,000 years (Fig. 2A). At a regional scale, climatic shifts around North and South America, Eurasia, and Africa at the time of extinction, although large, were not unusual (Fig. 2, B and C). If the extinction in Australia occurred before $40 \mathrm{ky} \mathrm{BP}$, it would have occurred when ocean records were relatively placid (Fig. 2B).

Long pollen records from areas with megafaunal remains are few, but they allow a first approximation of how the magnitude of floral change compares to the timing of extinction in various regions. The comparison requires converting published pollen records to a standardized scale (Fig. 3). In
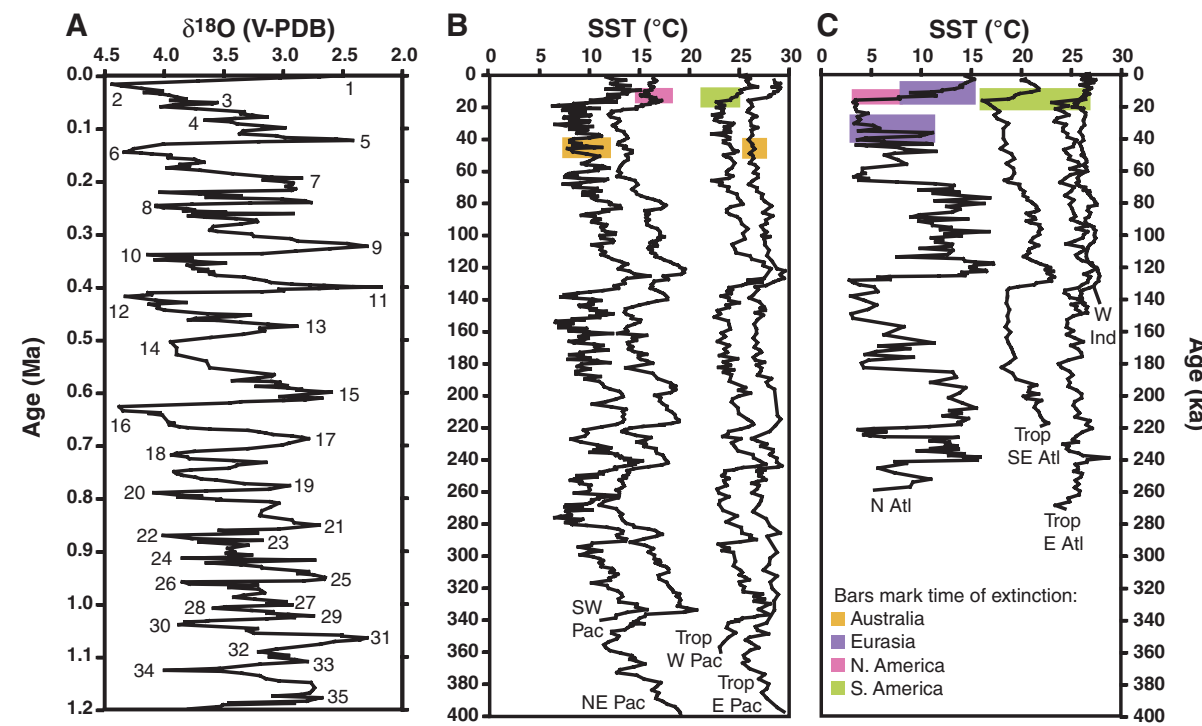

Fig. 2. (A) Oxygen isotope data from benthic foraminifera at North Atlantic Deep-Sea Drilling Program site $607(81,82)$. The isotopic signal $\left(\delta^{18} 0\right)$ in benthic foraminifera largely reflects variations in continental ice volume, with a smaller effect due to changes in ocean bottom temperatures. Numbers refer to marine isotope stages $(81,82)$. Most well-constrained extinctions and drops in abundance occurred in stages 2 and 3. V-PDB, Vienna-Pee Dee Belemnite. (B and C) Sea-surface temperature (SST) records from the (B) Pacific and (C) Atlantic and Indian oceans, respectively. Colored bars indicate the time of extinction on nearby continents. The core label, latitude, longitude, type of SST estimate, and source are as follows: northeast Pacific (NE Pac), Ocean Drilling Program (ODP) $1020,41.00^{\circ} \mathrm{N}, 126.43^{\circ} \mathrm{W}$, alkenone (83); tropical east Pacific (Trop E Pac), TR $163-9,2.26^{\circ} \mathrm{N}, 90.95^{\circ} \mathrm{W}, \mathrm{Mg} / \mathrm{Ca}$ (84); tropical west Pacific (Trop W Pac), ODP 806B, $1.32^{\circ} \mathrm{N}, 159.36^{\circ} \mathrm{E}, \mathrm{Mg} / \mathrm{Ca}(84)$; southwest Pacific (SW Pac), MD 97-2120, 45.53이 $174.93^{\circ} \mathrm{E}, \mathrm{Mg} / \mathrm{Ca}$ (85); west Indian ( $\mathrm{W}$ Ind), MD $85674,3.18^{\circ} \mathrm{N}, 50.43^{\circ} \mathrm{E}$, alkenone (86); north Atlantic (N Atl), K 708$1,50.00^{\circ} \mathrm{N}, 23.73^{\circ} \mathrm{W}$, foraminiferal transfer function (average of data reported for August and February) (87); tropical east Atlantic (Trop E Atl), GeoB 1112, $5.77^{\circ} \mathrm{S}, 10.75^{\circ} \mathrm{W}, \mathrm{Mg} / \mathrm{Ca}$ (88); and tropical southeast Atlantic (Trop SE Atl), GeoB $10285,20.10^{\circ} \mathrm{S}, 9.19^{\circ} \mathrm{E}$, alkenone (89). All ages in this figure are in calendar years (ky BP), not ${ }^{14} \mathrm{C}$ years (ky RCBP), using age models in primary publications, except for core K $708-1$, where ${ }^{14} \mathrm{C}$ ages reported in (87) were converted to calendar years with CALIB $98(90)$ from 0 to $22,000{ }^{14} \mathrm{C}$ years and with data from (91) for 22,000 to 45,000 ${ }^{14} \mathrm{C}$ years. 
some areas, vegetation change coincides with extinction (Fig. 3, E, G, and L), but in others it does not (Fig. 3, D, F, H, and M). Elsewhere, the last phases of extinction correlate with vegetation change but the initial extinctions may not (Fig. 3, I and J). In still other regions, extinctions are not well enough dated to compare with vegetation change (Fig. 3, A to $\mathrm{C}, \mathrm{K}$, and $\mathrm{N}$ ). Particularly interesting is northeastern Australia (Fig. 30), where the extinction may coincide with a rapid transition to full glacial biomes unlike any seen in 150,000 years, including the prior full glacial period around $130 \mathrm{ky} \mathrm{BP}$; this might support an environmental component to extinction at that location.

A generalized ecological model that has just begun to receive attention is that of state-changes in ecosystems, either when certain thresholds are crossed (67) or because of intrinsic nonlinear dynamics (68). Future work could gainfully explore whether the nature of climatic change in certain areas is consistent with threshold effects, as well as whether ecological sys- tems exhibit dynamical properties that indicate a susceptibility to collapse.

\section{Current State of the Evidence}

How far has the debate about Pleistocene extinction on continents progressed in the last 40 years? The case for humans contributing to extinction is now much stronger than it was in the early days, with support from recent work on chronology, simulations, paleoclimatology, paleontology, and archaeology. Yet it is an oversimplification to say that an abrupt wave of hunting-

\section{South \& North American Floral Records}

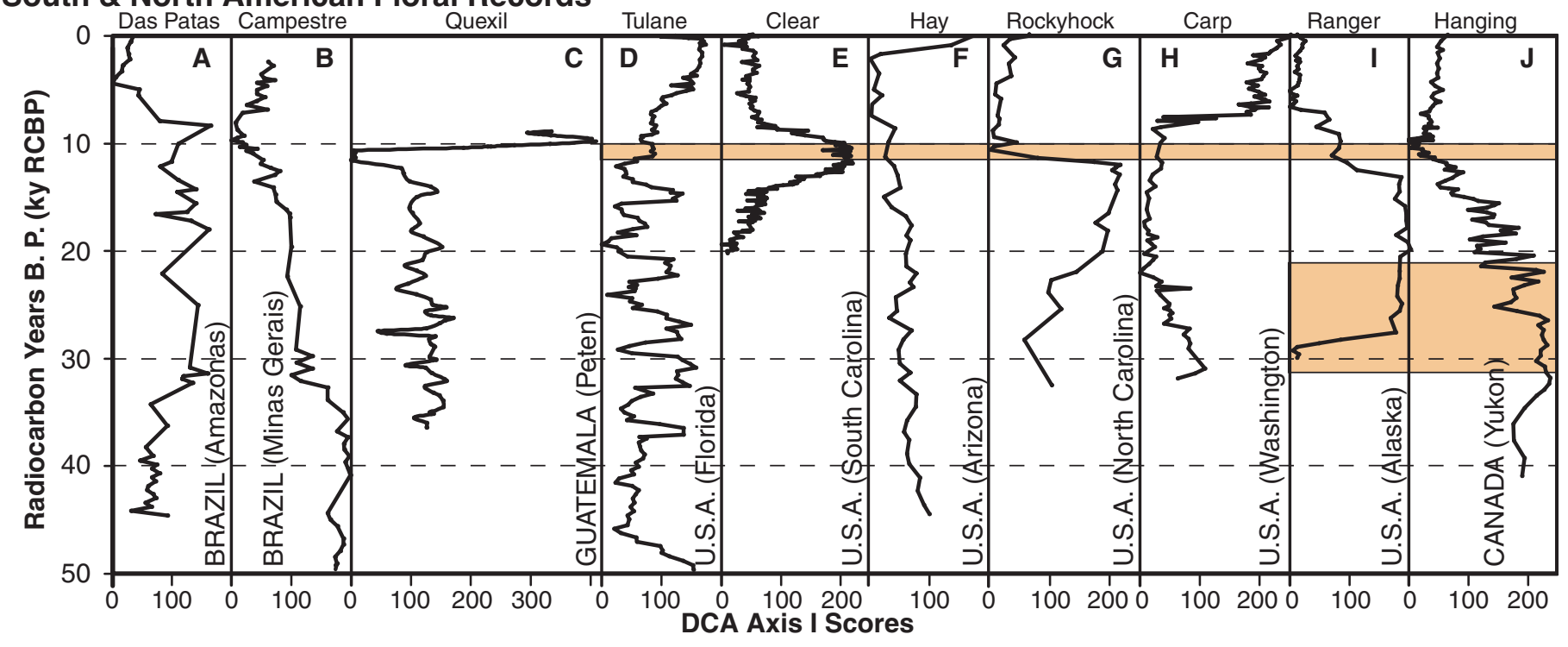

Fig. 3. Timing of vegetational changes in relation to timing of extinction (shaded intervals) in different parts of the world. Vegetation is inferred from published palynological records (78). The following list gives the site name with latitude, longitude, and elevation $(\mathrm{m})$ in parenthesis: (A) Lagoa das Patas $\left(0.3^{\circ} \mathrm{N}, 66.7^{\circ} \mathrm{W}, 300\right)$; (B) Lagoa Campestre (19.0 $\left.0^{\circ} \mathrm{S}, 46.8^{\circ} \mathrm{W}, 980\right)$; (C) Lake Quexil (coordinates not available); (D) Lake Tulane $\left(28.0^{\circ} \mathrm{N}, 82.0^{\circ} \mathrm{W}, 34\right) ;(\mathrm{E})$ Clear Pond $\left(33.8^{\circ} \mathrm{N}, 79.0^{\circ} \mathrm{W}, 10\right)$; (F) Hay Lake $\left(37.0^{\circ} \mathrm{N}, 109.0^{\circ} \mathrm{W}, 2780\right)$; (G) Rockyhock Bay $\left(36.0^{\circ} \mathrm{N}, 77.0^{\circ} \mathrm{W}\right.$, 6); (H) Carp Lake $\left(45.0^{\circ} \mathrm{N}, 121.0^{\circ} \mathrm{W}\right.$, 714); (I) Ranger Lake $\left(67.1^{\circ} \mathrm{N}\right.$, $\left.153.7^{\circ} \mathrm{W}, 820\right)$; (J) Hanging Lake $\left(68.0^{\circ} \mathrm{N}, 138.0^{\circ} \mathrm{W}, 500\right)$; (K) Nong Pa Kho $\left(17.0^{\circ} \mathrm{N}, 103.0^{\circ} \mathrm{E}, 180\right)$; (L) Jack London Lake $\left(62.2^{\circ} \mathrm{N}, 149.5^{\circ} \mathrm{E}, 820\right)$; (M) loannina I $\left(39.8^{\circ} \mathrm{N}, 20.7^{\circ} \mathrm{E}, 470\right)$; (N) Rusaka Swamp $\left(3.4^{\circ} \mathrm{S}, 29.6^{\circ} \mathrm{E}\right.$. 2070); and (O) Lynch's Lake $\left(17.4^{\circ} \mathrm{S}\right.$, $\left.145.7^{\circ} \mathrm{E}, 760\right)$. The different pollen Asian, European, African \& Australian Floral Records
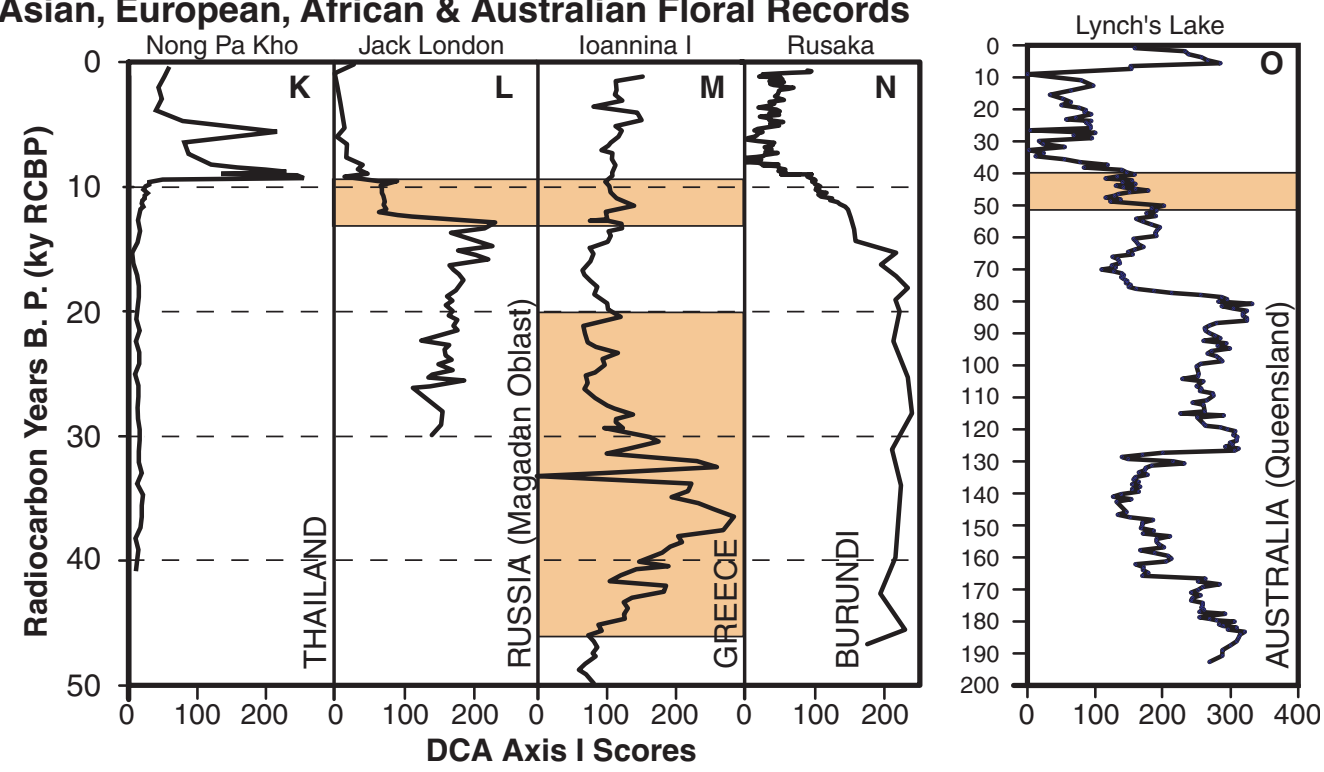
records were standardized for comparison by Detrended Correspondence Analysis (DCA); the DCA Axis I score is used to depict when pollen abundances shift, which in turn reflects changes in surrounding vegetation. The standardization proceeded by downloading the taxon abundance matrix for each core from (78), removing the aquatic taxa (e.g., floating and emergent aquatics and algae), and calculating the percent abundance for each terrestrial sporomorph type in each sample. Each matrix was

independently subjected to DCA with the software package MVSP 3.12a (92). Taxon abundances were unweighted and 26 segments were used in four detrending cycles. The score of each sample on the first axis of the DCA (which for these analyses expresses 20 to $40 \%$ of the total variation in the data set) is used to quantify its floral composition in relation to the other samples from the same core. The age of each sample is from the published age model (78) for each site. 
induced extinctions swept continents right after first human contact. Instead, the evidence shows that blitzkrieg sensu stricto can be firmly rejected in western Europe, Siberia, Alaska, and probably Australia and central North America. Without late Pleistocene climatic change, it is likely that species such as horses in Alaska and mammoths and giant Irish deer in central Eurasia would have survived longer, despite the presence of humans. The recent information now points toward humans precipitating the extinction, but also to an instrumental role for late Pleistocene climatic change in controlling its timing, geographic details, and perhaps magnitude. The mechanism for climatic effects is likely to be found in detailed species-by-species analyses (19), rather than in one of the three existing global ecological models $(10,59,60)$, none of which is fully consistent with observations.

Data density and quality are still uneven. The Eurasian record is increasingly good and reveals that late Pleistocene climatic change contributed to extinction by driving range adjustments in large mammals. An idea that needs further testing is that the arrival and population expansion of Homo sapiens sapiens began to fragment megafaunal ranges by 30,000 years ago, ultimately restricting megafauna to inviable populations in far northern refugia by the end of the Pleistocene. Australian evidence suggests that megafaunal extinction followed human arrival, and that both probably preceded significant global or regional South Pacific climatic change, which is consistent with a role for humans. However, the timing of key events still cannot be bracketed within error bars less than $\sim 10,000$ years, the youngest records of extinct megafauna are controversial, and local environmental changes may differ from the global or regional pattern $(4,5)$. In South America, published data on extinction chronology is accumulating but awaits critical analysis. In Africa, better temporal resolution is needed to assess how the timing of the few extinctions matches local environmental changes and human impacts.

In contrast, robust dating verifies simultaneous climatic change and first human contact in the conterminous United States, where extinctions were particularly rapid and pronounced. Support for human impacts includes (i) indisputable hunting of two extinct species, (ii) clustering of extinctions within 1,500 years (and perhaps less) of first contact with Clovis hunters, (iii) widespread distribution of Clovis hunters, (iv) simulations, and (v) more pronounced extinction than in mid-Pleistocene glacial-interglacial transitions. On a broader North American scale, the demise of megafaunal species without significant human presence in Alas- $\mathrm{ka}$ is consistent with some role for climate (11).

\section{General Implications}

The data show that the late Pleistocene extinction event was spread over more than 50,000 years globally; was the accumulation of diachronous, shorter-term pulses that took place on a regional basis; and was amplified by the interaction of both biotic (humans as invasive species) and abiotic (climatic) drivers.

A significant implication for conservation biology is that the coupling of marked climatic change with direct human impacts on fauna is especially pernicious. Both effects are under way today at unprecedented rates. Data generated in the Pleistocene extinctions debate are now robust enough to support earlier contentions (15) that the modern global ecosystem is unique in having vast populations of one species (humans) and a depauperate array of megafauna. The net effect, through loss of many herbivores, carnivores, and scavengers, has been simplification and loss of redundancy in food webs (69). This has implications for the stability of global ecosystems.

\section{Productive Future Directions}

The accumulated evidence suggests it is time to move beyond casting the Pleistocene extinction debate as a dichotomy of humans versus climate and instead to untangle the complex impacts that both had on megafauna. From the archaeological perspective, we need to know when human population sizes on each continent became large enough to affect vulnerable fauna. Kill-site and dating criteria must be standardized between continents. To understand the effects of environmental changes, much remains to be done in determining how changes in particular climatic parameters would have impacted population sizes of affected species. Particularly promising in this regard are advances in the study of fungal spores from megafaunal dung in lake sediments (70) and the use of ancient DNA to model population-level change (71-74). Improvements in the chronology of extinction and paleoclimatic reconstructions for South America and Africa are especially needed, as is a more detailed understanding of whether the last glacialinterglacial transition was different from earlier ones in pertinent ways. Rigorous, ecologically based models of range contraction and extinction must be formulated through linkage of work that has proceeded largely independently in paleoecology and ecology, especially in such areas as foodweb dynamics, keystone species, and ecosystem state-change. Some problems were intractable when the Pleistocene extinctions debate began but can now be addressed through new dating techniques $(7,75,76)$; through the assembly and analysis of paleoecological, paleoclimatic, and archaeological databases $(41,77,78)$; and through isotopic studies to reconstruct details of both the paleoclimate and paleoecology $(79,80)$.

\section{References and Notes}

1. P. S. Martin, R. G. Klein, Eds., Quaternary Extinctions: A Prehistoric Revolution (Univ. of Arizona Press, Tucson, 1984).

2. R. D. E. MacPhee, Ed., Extinctions in Near Time: Causes, Contexts, and Consequences (Kluwer/Plenum, New York, 1999).

3. A. J. Stuart, Biol. Rev. Camb. Philos. Soc. 66, 453 (1991).

4. S. Wroe, J. Field, R. Fullagar, L. S. Jermin, Alcheringa 28, 291 (2004).

5. Materials and methods are available as supporting material on Science Online.

6. J. M. Diamond, J. Archaeol. Sci. 16, 167 (1989).

7. R. G. Roberts et al., Science 292, 1888 (2001).

8. J. Alroy, Science 292, 1893 (2001).

9. R. D. Guthrie, Carnegie Mus. Nat. Hist. Spec. Publ. 8 482 (1984).

10. R. W. Graham, E. L. Lundelius Jr., in (1), pp. 223-249.

11. R. D. Guthrie, Nature 426, 169 (2003).

12. A. D. Barnosky, in Mass Extinctions: Processes and Evidence, S. K. Donovan, Ed. (Belhaven, London, 1989), pp. 235-254.

13. P. S. Martin, H. E. Wright Jr., Eds., Pleistocene Extinctions: The Search for a Cause (Proceedings of the VII Congress of the International Association for Quaternary Research, Yale Univ. Press, New Haven, CT, 1967), vol. 6

14. A. J. Stuart, in (2), pp. 257-270.

15. P. S. Martin, C. R. Szuter, Conserv. Biol. 13, 36 (1999).

16. A. D. Barnosky, E. A. Hadly, C. J. Bell, J. Mammal. 84, 354 (2003).

17. H. M. Regan, R. Lupia, A. N. Drinnan, M. A. Burgman, Am. Nat. 157, 1 (2001).

18. J. B. Callicott, J. Biosci. 27, 409 (2002).

19. D. K. Grayson, D. J. Meltzer, J. Archaeol. Sci. 30, 585 (2003)

20. S. L. Whittington, B. Dyke, in (1), pp. 451-465.

21. J. E. Mosimann, P. S. Martin, Am. Sci. 63, 304 (1975).

22. J. Alroy, in (2), pp. 105-143.

23. S. K. Lyons, F. A. Smith, J. H. Brown, Evol. Ecol. Res. 6, 339 (2004).

24. C. N. Johnson, Proc. R. Soc. London Ser. B 269, 2221 (2002).

25. N. G. Jablonski, M. J. Whitfort, N. Roberts-Smith, Q. Q. Xu, J. Hum. Evol. 41, 131 (2000).

26. D. K. Grayson, J. World Prehist. 15, 1 (2001).

27. A. D. Barnosky, Science 228, 340 (1985).

28. A. D. Barnosky, Quat. Res. 25, 128 (1986)

29. R. D. Guthrie, Nature 429, 746 (2004).

30. D. K. Grayson, Science 294, 1459 (2001).

31. S. J. Fiedel, G. Haynes, J. Archaeol. Sci. 31, 121 (2004).

32. D. K. Grayson, D. J. Meltzer, J. Archaeol. Sci. 31, 133 (2004).

33. M. I. Budyko, Sov. Geogr. Rev. Transl. 8, 783 (1967).

34. A. Anderson, J. Archaeol. Sci. 16, 137 (1989).

35. R. N. Holdaway, C. Jacomb, Science 287, 2250 (2000).

36. D. Choquenot, D. M. J. S. Bowman, Global Ecol. Biogeogr. Lett. 7, 167 (1998).

37. B. W. Brook, D. M. J. S. Bowman, Proc. Natl. Acad. Sci. U.S.A. 99, 14624 (2002).

38. G. E. Belovsky, J. Anthropol. Archaeol. 7, 329 (1988).

39. B. Winterhalder, F. Lu, Conserv. Biol. 11, 1354 (1997).

40. J. Alroy, Science 294, 1461 (2001).

41. FAUNMAP Working Group, Ill. Mus. Sci. Pap. 25, 1 (1994).

42. O. Bar-Yosef, Annu. Rev. Anthropol. 31, 363 (2002).

43. S. L. Kuhn, M. C. Stiner, in Hunter-Gatherers: An Interdisciplinary Perspective, C. Panter-Brick, R. H. Layton, P. Rowley-Conwy, Eds. (Cambridge Univ. Press, Cambridge, 2001), pp. 99-142.

44. H. Thieme, Nature, 385, 807 (1997). 
45. J. Kutzbach et al., Quat. Sci. Rev. 17, 473 (1998).

46. D. K. Grayson, in Handbook of North American Indians: Environment, Origins, and Population (Smithsonian Institution Press, Washington, DC, in press), vol. 3.

47. A. J. Stuart, L. D. Sulerzhitsky, L. A. Orlova, Y. V Kuzmin, A. M. Lister, Quat. Sci. Rev. 21, 1559 (2002).

48. R. D. E. MacPhee et al., J. Archaeol. Sci. 29, 1017 (2002).

49. S. L. Vartanyan, V. E. Garutt, A. V. Sher, Nature 362 337 (1993)

50. S. Gonzalez, A. C. Kitchener, A. M. Lister, Nature 405 753 (2000).

51. J. R. Dodson, R. Fullagar, J. Furby, R. Jones, I. P. Prosser, Archaeol. Oceania 28, 94 (1993).

52. J. Field, R. Fullagar, G. Lord, Antiquity 75, 696 (2001).

53. T. F. Lynch, Am. Antiq. 55, 12 (1990).

54. D. J. Meltzer et al., Am. Antiq. 62, 659 (1997).

55. M. T. Alberdi, L. Miotti, J. L. Prado, J. Archaeol. Sci. 28, 411 (2001)

56. T. D. Dillehay, The Settlement of the Americas: A New Prehistory (Basic Books, New York, 2000).

57. D. K. Grayson, D. J. Meltzer, J. World Prehist. 16, 313 (2002).

58. G. Haynes, The Early Settlement of North America: The Clovis Era (Cambridge Univ. Press, Cambridge, 2002).

59. N. Owen-Smith, Paleobiology 13, 351 (1987).

60. R. D. Guthrie, in (1), pp. 259-298.

61. S. L. Vartanyan, K. A. Arslanov, T. V. Tertychnaya, S. B. Chernov, Radiocarbon 37, 1 (1995).

62. R. W. Graham, T. W. Stafford, E. Lundelius, H. A Semken, J. Southen, paper presented at the 67th Annual Meeting of the Society of American Archaeology, Denver, CO, 20 to 24 March, 2002.

63. D. K. Grayson, J. World Prehist. 5, 193 (1991)

64. K. C. Moriarty, M. T. McCulloch, R. T. Wells, M. C. McDowell, Palaeogeogr. Palaeoclimatol. Palaeoecol. 159, 113 (2000)

65. A. D. Barnosky et al., Proc. Natl. Acad. Sci. U.S.A. 101, 9297 (2004).
66. A. D. Barnosky, Ed., Biodiversity Response to Climate Change in the Middle Pleistocene: The Porcupine Cave Fauna from Colorado (Univ. of California Press, Berkeley, 2004).

67. M. Scheffer, S. R. Carpenter, J. A. Foley, C. Folke, B. Walker, Nature 113, 591 (2001).

68. M. A. Forster, Oikos 103, 235 (2003).

69. R. V. Solé, J. M. Montoya, Proc. R. Soc. London Ser. B 268, 2039 (2001).

70. D. A. Burney, G. S. Robinson, L. P. Burney, Proc. Natl. Acad. Sci. U.S.A. 100, 10800 (2003).

71. I. Barnes, P. Matheus, B. Shapiro, D. Jensen, A. Cooper, Science 295, 2267 (2002).

72. E. A. Hadly, M. H. Kohn, J. A. Leonard, R. K. Wayne, Proc. Natl. Acad. Sci. U.S.A. 95, 6893 (1998)

73. E. A. Hadly, M. Tuinen, Y. Chan, K. Heiman, J. Mammal. 84, 403 (2003)

74. E. A. Hadly et al., PLoS Biol. 2, e290, in press; published online 7 September 2004 (10.1371/journal. pbio.0020290)

75. T. W. Stafford Jr. et al., Geology 27, 903 (1999).

76. E. Bard, F. Rostek, G. Ménot-Combes, Science 303, 178 (2004).

77. D. G. Anderson, M. K. Faught, A North American Paleoindian Database (www.anthro.fsu.edu/research/ paleo/paleoind.html) [cited January 2004]

78. Contributors to the Modern and Fossil Pollen Data Bank, International Geosphere-Biosphere Program Past Global Changes (IGBP PAGES)/World Data Center for Paleoclimatology, National Oceanic and Atmospheric Administration/National Geophysical Data Center Paleoclimatology Program, available at www.ngdc.noaa. gov/paleo/pollen.html (2004).

79. P. L. Koch, Annu. Rev. Earth Planet. Sci. 26, 573 (1998).

80. M. J. Kohn, T. E. Cerling, in Phosphates: Geochemical, Geobiological and Materials Importance, M. J. Kohn, J. Rakovan, J. M. Hughes, Eds. (Reviews in Mineralogy and Geochemistry, Mineralogical Society of America, Washington, DC, 2002), vol. 48, pp. 455-488.
81. W. F. Ruddiman, M. E. Raymo, D. G. Martinson, B. M. Clement, J. Backman, Paleoceanography 4, 353 (1989).

82. M. E. Raymo, W. F. Ruddiman, J. Backman, B. M. Clement, D. G. Martinson, Paleoceanography 4, 413 (1989).

83. T. D. Herbert et al., Science 293, 71 (2001).

84. D. W. Lea, D. K. Pak, H. J. Spero, Science 289, 1719 (2000).

85. K. Pahnke, R. Zahn, H. Elderfield, M. Schulz, Science 301, 948 (2003).

86. E. Bard, F. Rostek, C. Sonzogni, Nature 385, 707 (1997).

87. J. Imbrie et al., Paleoceanography 7, 701 (1992).

88. D. Nuernberg, A. Mueller, R. R. Schneider, Paleoceanography 15, 124 (2000).

89. R. R. Schneider, P. J. Mueller, G. Ruhland, Paleoceanography 10, 197 (1995).

90. M. Stuiver et al., Radiocarbon 40, 1041 (1998).

91. J. W. Beck et al., Science 292, 2453 (2001).

92. Kovach Computing Services, Multi-Variate Statistical Package, available at www.kovcomp.co.uk.

93. We thank the NSF for funding aspects of this research; contributors to the European, North American, Latin American, and Indo-Pacific pollen databases for making their data available online; D. K. Grayson, P. Martin, and five anonymous reviewers for comments on earlier versions of the manuscript, and students and faculty who contributed to the lively discussions on these issues in seminars at the University of California Berkeley and Santa Cruz campuses. This is contribution no. 1863 from the University of California Museum of Paleontology.

Supporting Online Material

www.sciencemag.org/cgi/content/full/306/5693/70/DC1 Materials and Methods

SOM Text

Tables S1 to S3

References and Notes

\section{Science \\ Gill MD. Functional Genomics Web Site}

- Links to breaking news in genomics and biotech, from Science, ScienceNOW, and other sources.

- Exclusive online content reporting the latest developments in post-genomics.

- Pointers to classic papers, reviews, and new research, organized by categories relevant to the post-genomics world.

- Science's genome special issues.

- Collections of Web resources in genomics and post-genomics, including special pages on model organisms, educational resources, and genome maps.

- News, information, and links on the biotech business.

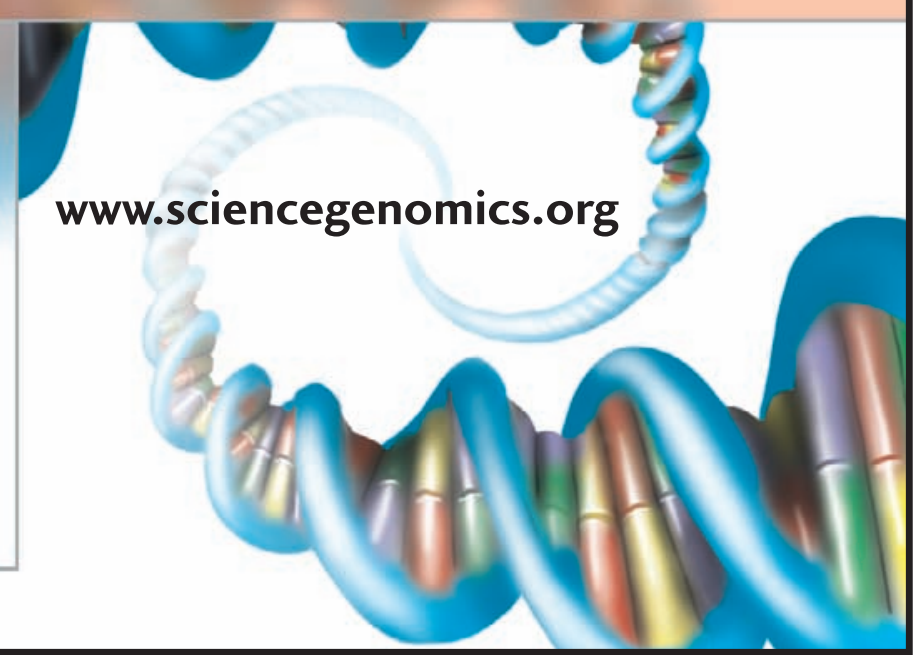




\title{
Assessing the Causes of Late Pleistocene Extinctions on the Continents
}

\author{
Anthony D. Barnosky ${ }^{1 *}$, Paul L. Koch ${ }^{2}$, Robert S. Feranec ${ }^{1}$, Scott L. Wing ${ }^{3}$, Alan \\ B. Shabel ${ }^{1}$ \\ ${ }^{1}$ Department of Integrative Biology and Museums of Paleontology and Vertebrate Zoology, University of \\ California, Berkeley, CA 94720 USA. ${ }^{2}$ Department of Earth Sciences, University of California, Santa \\ Cruz, CA 95064 USA. ${ }^{3}$ Department of Paleobiology, National Museum of Natural History, Smithsonian \\ Institution, Washington, D. C. 20560 USA \\ * To whom correspondence should be addressed. E-mail: barnosky@socrates.berkeley.edu
}

\section{Supporting Online Material}

\section{Methods and Definitions}

Intensity of the Pleistocene Extinction. The total number of extinct genera is 121 (Table S1) if one counts those that disappeared from at least one continent (versus 97 global extinctions). The extinction preferentially stripped the large mode or tail from mammalian body size distributions in the Americas and Australia (1). In North America, the only continent where the Pleistocene extinction has been comprehensively compared to earlier Cenozoic mammalian extinction events (2), the Pleistocene event is unusual in intensity and in preferentially affecting large mammals $(\geq 10 \mathrm{~kg})$. Similar analyses have yet to be done for other continents; an underlying assumption of all past studies is that the extinction is unique in these respects worldwide.

Taxonomy. Following past analyses, we focus on genera because species-level taxonomy is less stable. We used ref. (3) for a standardized taxonomy.

Radiometric-Age Terminology. When possible, dates for the last 45,000 years are expressed in units of 1000 radiocarbon years before present (ky RCBP). Dates calibrated to calendar years from this interval and dates from before this interval are reported as ky or my (million years) BP.

Human Impacts on Fauna. "Overkill” means that human hunting precipitated extinction by causing death rate to exceed birth rate, with the process taking 1500 years or more (4). "Blitzkrieg" is a special case of overkill, in which hunting by humans was so intense that it 
caused extinction in less than about 500 years, with extinctions occurring more rapidly along a geographic front (5). Both overkill and blitzkrieg are plausible based on hunting behavior of industrialized and non-industrialized humans $(1,6)$, but extrapolating modern human behaviour into the past is problematic. Extinction through habitat alteration, or sitzkrieg (7), was proposed as an alternative to blitzkrieg and gradual overkill. The sitzkreig model has been postulated especially for Australia, where human alteration of the landscape by fire has been suggested as a major driver of extinction (8-10).

\section{Explanatory Text}

\section{Simulations}

Table S2 summarizes the simulations that have been developed to test the overkill theory. In general, early simulations that focus on entry of Clovis hunters into North America had mixed results and some exhibited intrinsic dynamical instability. Those that focus on extinction of moas in New Zealand suggest overkill is probable and blitzkrieg may be possible under certain assumptions. Simple optimal foraging models with just 1 or 2 prey items typically do not support overkill, whereas those with more variable prey support overkill under certain circumstances. Early models tailored to examine Aboriginal impacts in parts of Australia, or that examined the effects of prey naiveté on single species, did not support overkill as a general result. The Alroy simulation (11), which involves multiple species with realistic geographic ranges and population dynamics, but without selective human foraging, supports overkill under a range of conditions.

The Alroy Simulation. In the Alroy simulation, an error in the parameterization of prey $r$ values makes it difficult to assess the reported sensitivity tests (12), but a subsequent correction (13) reran the best-fit trial with appropriate $r$ values, and correctly predicted the fate of 34 of 41 species with final human population densities of $\sim 28$ people/100 $\mathrm{km}^{2}$ getting $\sim 30 \%$ of their calories from large animals. The median time to extinction was 895 years, supporting overkill but too slow for blitzkrieg sensu stricto.

The chief critiques of this simulation were (i) that it failed to account for the low number of kill-sites in North America, especially the lack of kill-sites for many extinct species $(14,15)$ and (ii) that it over-predicted overkill because it did not allow prey to lose naiveté to human hunters as their numbers diminished (16). As discussed in the printed text and in greater detail below, for most species the missing kill-site critique is weak. "Prey-hardening" to the hunting 
techniques of predators is hard to quantify, but in simulations of predation on single species, particularly those with fixed, low human densities, inclusion of hardening should certainly decrease the probability of overkill, as demonstrated in ref. (16). Ref. (16) did not simulate human population densities as high as those in Alroy's revised best fit scenario, and did not examine a multi-species case that allowed prey switching, so it is not surprising that they found overkill less likely. In addition, a recently published sensitivity analysis based on this model commonly yielded size selective overkill that closely matched observations, despite moderate loss of naïveté (17). Finally, in the real world, where humans are simultaneously hunting many species with variable intrinsic rates of increase, the only sure-fire hardening method would be flight to depopulated refugia. This may explain why many extinct taxa had their last occurrences in the high Arctic (18), or on isolated islands $(19,20)$, or why many surviving slow-breeders are alpine, deep-forest, nocturnal, arboreal or high-latitude (21).

\section{Chronology}

Eurasia, Alaska, and the Yukon. In Eurasia, warm-adapted megafauna that were abundant during preceding interglacials (straight-tusked elephants, hippos) became extinct between 45 and 20 ky RCBP (22). In Alaska and the Yukon, hemionid horses (23) and shortfaced bears became extinct at $\sim 31$ and 21 ky RCBP, respectively. The second pulse of extinctions began near the Younger Dryas (YD) and hit cold-adapted animals. Datable mammoth fossils dropped in abundance across Europe and Alaska after 12 ky RCBP, arguably indicating a decrease in effective population sizes then; however, mammoths survived until 9.7 ky RCBP on the Taimyr Penisula, 3.7 ky RCBP on Wrangell Island, and 7.9 ky RCBP on St. Paul Island $(18,19,24)$. In western Europe, giant Irish deer dropped in abundance and began to dwarf during the YD (25) before disappearing as recently as $\sim 9.2 \mathrm{ky} \operatorname{RCBP}(26)$. In Alaska, caballoid horses began to dwarf at $25 \mathrm{ky}$ RCBP and became extinct at $12.5 \mathrm{ky}$ RCBP (23). The small number of datable fossils seems to indicate a population crash for many species near the Pleistocene-Holocene boundary in Eurasia and Alaska, including both ultimate victims and animals that survived into recent times somewhere in the Holarctic (18). In general, warmadapted species disappeared as Last Glacial Maximum (LGM) glacial conditions developed and cold-adapted species moved north as the LGM ended and climates warmed, just as they had at prior glacial-interglacial transitions (22). In some cases, such as the extinction of Irish deer in 
Ireland $(25,27)$, or the loss of short-faced bears and both horse species in Alaska and the Yukon $(23,28)$, the disappearances occurred before apparent sign of human contact.

Australia. The Australian extinction and human occupation chronologies are for the most part too old for radiocarbon dating, but dates have been supplied by new, though less precise techniques such as optical luminescence, amino acid racemization, and ${ }^{230} \mathrm{Th} /{ }^{234} \mathrm{U}$ dating of sediments $(9,29)$. Many of the fossils are from caves or other complex deposits; thus, accepted dates rely on a stringent set of criteria that includes articulation of remains (29), which minimizes the potential of including bones that have been moved from their original sedimentary context. Abundant dates using amino acid racemization, accelerator mass spectrometry (AMS), ${ }^{14} \mathrm{C}$ and thermal ionization mass spectometry (TIMS), and luminescence dates on Genyornis eggshells and associated sediment supports extinction of that large bird about $50 \mathrm{ky}(9)$. Controversy remains about criteria for accepting dates and about which sites should be considered as providing robust evidence (30). Recent work (30) suggests that megafauna persisted longer than the reported youngest limit of about $40 \mathrm{ky}$ (29). Should younger dates such as those reported for Cuddie Springs prove reliable (30), and should it be demonstrated that that local environmental history is decoupled from the regional paleoclimate proxies afforded by South Pacific marine curves, it would weaken the argument that humans were the primary agent of extinction in Australia. In any case the overlap of humans with megafauna for the several thousands of years that now seems likely would refute blitzkrieg in Australia.

Africa. In Africa, only 8 genera of Pleistocene megafauna went extinct; 3 of these were known only from north Africa, and 2 only from south Africa $(31,32)$. Extinction of 5 genera cannot be dated more precisely than the last 100 ky BP; 3 went extinct in the Holocene.

\section{Archaeology and Paleontology}

Few kill-sites (as defined by stringent standards such as a spearpoint intermingled with fossil bones) are verified in North America, but associations between archaeological remains and megafaunal bones are more common than kill-sites sensu stricto (33). In Eurasia and Africa humans hunted extinct megafauna long before the extinction event (34). Still, ref. (35) observes that there are more well-documented proboscidean kill-sites from the latest Pleistocene of North America than there are from all of Africa over the past 100,000 years. This no doubt reflects the extreme rarity of fossil and archaeological site preservation, discovery and analysis. These 
differences between Eurasia, Africa, and North America have called overkill models into question, but are largely explainable by the fact that different criteria are used to accept evidence that humans were utilizing megafauna on the different continents. In Australia, there is no evidence for direct human modification of extinct megafauna $(30,36)$, and lithic artifacts and extinct Pleistocene megafauna have been found in stratigraphic association only at Cuddie Springs (37). In South America, evidence for utilization of extinct megafauna by humans exists at a few sites $(38,39)$, and artifacts and extinct megafauna are associated at a number of sites $(40)$.

Missing Kill Sites. Previous analyses (33) have assessed the ratio of kill-sites to paleontological occurrences by comparing the number of securely-documented kill sites with the total number of Pleistocene fossil sites reported for a given taxon (41). Still needed is comparison of the number of kill-sites or archaeological associations with only the number of late Pleistocene occurrences for various taxa (rather than with all Pleistocene occurrences). The FAUNMAP database (41), combined with rigorous application of kill-site criteria (33), provides one way to estimate this for North America, where much controversy has centered. We assumed that the ratio of Clovis age mammoth kill sites to all late-glacial FAUNMAP mammoth sites approximates the frequency at which kill sites might be preserved, and applied a chi-square test that compares the mammoth kill-site ratio to those for other taxa (Table S3). We discovered that (1) a high proportion of late-glacial mammoth sites (27\%) are well-documented kill-sites; (2) Platygonus may be represented at fewer kill-sites than would be expected; and (3) most taxa are too rare in the fossil record to say whether or not their frequency of kill sites differs significantly from Mammuthus. Using the low Mammut ratio as the kill-site standard suggests that no other taxa are known at enough sites for kill sites to be expected, except for Mammuthus, which by comparison was hunted exceptionally often. Megafauna sites in minimally acceptable archaeological context exceed $40 \%$ of the total late-glacial sites known for Camelops, Capromeryx, Equus, Hemiauchenia, and Mammuthus (Table S3). "Minimally acceptable archaeological context" means that the sites pass the first cut of the stringent vetting applied by reference (33), but do not provide irrefutable evidence that humans were killing or using the animals. 
Comparison of similarly standardized data sets for all continents would clarify where the numbers of archaeological associations with extinct megafauna or kill sites was significantly high or low.

\section{Climatic Change and Ecological Effects}

Climatic extinction models regard climate as causing unusual late Pleistocene vegetation changes, which in turn affected the fauna. Several glacial-interglacial cycles preceded the last one, but did not cause megafaunal extinction $(22,42-45)$. Thus, any extinction models that rely on climatic change must specify differences between the last glacial-interglacial cycle and previous ones. Also, climate-extinction models must be consistent with what we know about how animals react to unusual climatic changes.

Summary of Relevant Climatic Changes. The Earth began to experience pronounced cycles between glacial and interglacial conditions $\sim 2.5$ myr BP (46). These cycles were paced by orbitally-driven changes in insolation. Low amplitude cycles with a $41 \mathrm{ky}$ frequency gave way to $100 \mathrm{ky}$ cycles $\sim 1.2 \mathrm{my} \mathrm{BP}$, and the amplitude of the $100 \mathrm{ky}$ cycles became more pronounced $\sim 600 \mathrm{ky} \mathrm{BP}$ (Fig. 2A). In each 100 ky cycle, maximum glaciation lasting $\sim 10$ ky was generally followed by $\sim 10$ ky of maximum interglacial warmth, which then was followed by a long, stepped decline back to full glacial conditions over the next $80 \mathrm{ky}$.

Glacial/interglacial transitions were accompanied by changes in atmospheric and ocean circulation, sea level, atmospheric composition, seasonality of temperature and precipitation, position of storm tracks, monsoonal activity, vegetation assemblages and many other parameters. The magnitude of response on land varied with latitude, altitude, and distance from the ocean. At the Last Glacial Maximum (LGM), $\sim 18 \mathrm{ky} \mathrm{RCBP,} \mathrm{temperatures} \mathrm{were} 2-5^{\circ} \mathrm{C}$ cooler than today at low altitudes near the equator, and $10-20^{\circ} \mathrm{C}$ colder at higher latitudes and altitudes (47) (Fig. 2B,C).

Large amplitude climate oscillations also occurred on a sub-orbital, millennial time scale through full glacial and transitional intervals, and perhaps in some of the interglacial intervals $(48,49)$. Sub-orbital climate variability was strong during the LGM-Holocene transition. In the northern hemisphere, a sudden, sharp cold snap, the Younger Dryas (YD) event, beginning 11 ky RCBP ( 12.9 ky BP) abruptly reversed a warming trend that had been accompanied by widespread deglaciation (Fig. 2C). The YD, which may have been more extreme than earlier 
reversals in deglaciation (50), ended abruptly at $\sim 10$ ky RCBP $(\sim 11.6 \mathrm{ky} \mathrm{BP})$, and warm conditions leading to the current interglacial prevailed. While some southern hemisphere climate records show YD cooling, others show a gradual warming (51).

Faunal Response to Current Climatic Warming. The response of biota to current, anthropogenically-induced global warming, which may be faster than the end-Pleistocene warming $(52,53)$, does not yet include megafaunal extinction, although simulations suggest substantial extinction may eventually result (54). Most documented biotic effects of warming are on taxa of low trophic level and small body size $(55,56)$, but geographic ranges and population density of large ungulates have also been affected (55, 57-59). Pronounced range shifts of both small and large mammals have been documented at the late Pleistocene extinction event, and generally are attributed at least partly to climatic influences $(22,41,42,60,61)$.

\section{Faunal Response to Earlier Pleistocene Glacial-Interglacial Transitions.}

Records of how mammal communities responded to prior Pleistocene glacial-interglacial transitions have long been known from Europe $(22,42)$ and have recently been reported from North America and Australia $(43,44)$. The latter are informative in that humans were absent during the earlier climatic transitions and reveal that diversity patterns, size, trophic, and taxonomic structure changed more from the late Pleistocene to the late Holocene than they had in the previous million years. Where data are sufficient, the climatic changes that precipitated faunal change at these earlier glacial-interglacial transitions, in the absence of humans, seem to have affected lower size and trophic categories (62). Such bottom-up changes also characterized the late Pleistocene-Holocene transition, but added to them were the top-down impacts that resulted in megafaunal extinction.

Keystone Species Model. Proboscideans have been proposed as late Pleistocene keystone species, with their removal by either humans or climatic change leading to shifts in vegetation and cascading impacts on other species (63).

Co-evolutionary Disequilibrium Model. Co-evolutionary disequilibrium posits that strong niche-partitioning among Pleistocene herbivores was disrupted by an unusually rapid transition to new Holocene biomes. The assumption of resource-partitioning among herbivores is supported by recent isotopic studies of paleodiet $(64,65)$.

Mosaic-Nutrient Model. The mosaic-nutrient model, developed for Beringian biomes, argues that climate changed such that the growing season and local plant diversity decreased, and 
plant anti-herbivore defences increased. The model assumes that extinct caecal fermenters needed a greater diversity of forage types than ruminants, and were thus more susceptible to nutritional stress in Holocene biomes. Isotopic data from Texas and Florida do not offer strong support for these assumptions about diet, though they show that the few surviving herbivores (e.g, bison, deer) had very homogeneous diets $(64,65)$. 
Table S1. Extinct genera on each continent. Placement within one of the age bins is based on our vetting of the literature to extract the youngest reliably dated occurrence (see footnotes $\mathrm{d}, \mathrm{e}, \mathrm{i}$ ). The age assignments are conservative, in that we required a date robust enough to allow a genus to be placed within the bracketing ages of each bin; and (ii) for ages younger than $50 \mathrm{ky}$, the last records of some genera are dated to shorter intervals within each of the age bins shown in the table.

\begin{tabular}{|c|c|c|c|c|c|c|c|}
\hline \# & TAXON & $\begin{array}{c}\text { LAST } \\
100 \\
k^{\mathrm{g}}\end{array}$ & $\begin{array}{c}100- \\
50 \mathrm{ky}\end{array}$ & $\begin{array}{c}50-13 \\
\text { ky } \\
\text { RCBP }\end{array}$ & $\begin{array}{c}13-10 \\
k y \\
\text { RCBP }\end{array}$ & HOLOCENE ${ }^{\mathrm{h}}$ & REFERENCE ${ }^{\mathrm{i}}$ \\
\hline & AFRICA & & & & & & \\
\hline & Mammalia & & & & & & \\
\hline & Proboscidea & & & & & & \\
\hline & Elephantidae & & & & & & \\
\hline \multirow[t]{3}{*}{1} & Elephas & $\mathrm{X}$ & & & & & $(66)$ \\
\hline & Perissodactyla & & & & & & \\
\hline & Equidae & & & & & & \\
\hline \multirow[t]{3}{*}{2} & Hipparion & $\mathrm{X}$ & & & & & $(66)$ \\
\hline & Artiodactyla & & & & & & \\
\hline & Camelidae & & & & & & \\
\hline \multirow[t]{2}{*}{3} & Camelus & $\mathrm{X}$ & & & & & $(66)$ \\
\hline & Cervidae & & & & & & \\
\hline \multirow[t]{2}{*}{4} & Megaceroides ${ }^{\mathrm{a}}$ & $\mathrm{X}$ & & & & & $(66)$ \\
\hline & Bovidae & & & & & & \\
\hline 5 & Megalotragus & & & & & $\mathrm{x}$ & $(67)$ \\
\hline 6 & Pelorovis & & & & & $\mathrm{X}$ & $(68)$ \\
\hline 7 & Parmularius & $\mathrm{X}$ & & & & & $(66)$ \\
\hline \multirow[t]{5}{*}{8} & Bos & & & & & $\mathrm{X}$ & (3) \\
\hline & & & & & & & \\
\hline & AUSTRALIA & & & & & & \\
\hline & Reptilia & & & & & & \\
\hline & Varanidae & & & & & & \\
\hline \multirow[t]{2}{*}{9} & Megalania & & & $\mathrm{X}$ & & & (29) \\
\hline & Meiolanidae & & & & & & \\
\hline 10 & Meiolania & & & $\mathrm{X}$ & & & (29) \\
\hline \multirow[t]{2}{*}{11} & Ninjemys & $\mathrm{X}$ & & & & & (69) \\
\hline & Crocodylidae & & & & & & \\
\hline 12 & Palimnarchus & & & $\mathrm{X}$ & & & (29) \\
\hline \multirow[t]{2}{*}{13} & Quinkana & & & $\mathrm{X}$ & & & (29) \\
\hline & Boiidae? & & & & & & \\
\hline \multirow[t]{2}{*}{14} & Wonambi & & $\mathrm{X}$ & & & & (29) \\
\hline & Aves & & & & & & \\
\hline \multirow[t]{4}{*}{15} & Genyornis & & & $\mathrm{X}$ & & & (29) \\
\hline & Mammalia & & & & & & \\
\hline & Marsupialia & & & & & & \\
\hline & Diprotodontidae & & & & & & \\
\hline 16 & Diprotodon $^{\mathrm{b}}$ & & & $\mathrm{X}$ & & ? & (29) \\
\hline 17 & Euryzygoma & $\mathrm{X}$ & & & & & $(69)$ \\
\hline 18 & Euowenia & $\mathrm{X}$ & & & & & (69) \\
\hline 19 & Nototherium & $\mathrm{X}$ & & & & & $(69)$ \\
\hline \multirow[t]{2}{*}{20} & Zygomaturus & & $\mathrm{X}$ & & & & $(29)$ \\
\hline & Palorchestidae & & & & & & \\
\hline
\end{tabular}




\begin{tabular}{|c|c|c|c|c|c|c|c|}
\hline 21 & Palorchestes & & & $\mathrm{X}$ & & & (29) \\
\hline & Vombatidae & & & & & & \\
\hline 22 & Phascolomys & $\mathrm{X}$ & & & & & (69) \\
\hline 23 & Phascolonus & & & $\mathrm{X}$ & & & (29) \\
\hline \multirow[t]{2}{*}{24} & Ramsayia & $X$ & & & & & (69) \\
\hline & Thylacoleonidae & & & & & & \\
\hline \multirow[t]{2}{*}{25} & Thylacoleo & & & $\mathrm{X}$ & & & (29) \\
\hline & Macropodidae & & & & & & \\
\hline 26 & Protemnodon & & & $X$ & & & (29) \\
\hline 27 & Procoptodon & $\mathrm{X}$ & & & & & (69) \\
\hline 28 & Simosthenurus & & & $\mathrm{X}$ & & & (29) \\
\hline \multirow[t]{5}{*}{29} & Sthenurus & & $\mathrm{X}$ & & & & (29) \\
\hline & EURASIA & & & & & & \\
\hline & Mammalia & & & & & & \\
\hline & Carnivora & & & & & & (42) \\
\hline & Hyaenidae & & & & & & \\
\hline \multirow[t]{2}{*}{30} & Crocuta & & & & $\mathrm{X}$ & & $(42)$ \\
\hline & Proboscidea & & & & & & (42) \\
\hline 31 & Mammuthus & & & & $\mathrm{X}$ & & (42) \\
\hline \multirow[t]{3}{*}{32} & Palaeoloxodon & & $\mathrm{X}$ & & & & $(42)$ \\
\hline & Perissodactyla & & & & & & (42) \\
\hline & Rhinocerotidae & & & & & & \\
\hline 33 & Dicerorhinus & & & $X$ & & & (42) \\
\hline \multirow[t]{3}{*}{34} & Coelodonta & & & & $\mathrm{X}$ & & (42) \\
\hline & Artiodactyla & & & & & & (42) \\
\hline & Hippopotamidae & & & & & & \\
\hline \multirow[t]{2}{*}{35} & Hippopotamus & & $\mathrm{X}$ & & & & (42) \\
\hline & Camelidae & & & & & & \\
\hline \multirow[t]{2}{*}{$?$} & Camelus & & & & $?$ & & (42) \\
\hline & Cervidae & & & & & & \\
\hline \multirow[t]{2}{*}{36} & Megaloceros & & & & & $\mathrm{X}$ & (26) \\
\hline & Bovidae & & & & & & \\
\hline 37 & Spirocerus & & & $\mathrm{X}$ & & & (42) \\
\hline \multirow[t]{6}{*}{38} & Ovibos & & & & & $X$ & (42) \\
\hline & & & & & & & \\
\hline & NORTH AMERICA $^{C}$ & & & & & & \\
\hline & Mammalia & & & & & & \\
\hline & Xenarthra & & & & & & \\
\hline & Glyptodontidae & & & & & & \\
\hline \multirow[t]{2}{*}{39} & Glyptotherium & $X$ & & & & & $(70)$ \\
\hline & Megalonychidae & & & & & & \\
\hline \multirow[t]{2}{*}{40} & Megalonyx & & & & $\mathrm{X}$ & & (42) \\
\hline & Megatheriidae & & & & & & \\
\hline 41 & Eremotherium & $X$ & & & & & $(70)$ \\
\hline \multirow[t]{2}{*}{42} & Nothrotheriops & & & & $\mathrm{X}$ & & (42) \\
\hline & Mylodontidae & & & & & & \\
\hline \multirow[t]{2}{*}{43} & Glossotherium & & & $\mathrm{X}$ & & & (42) \\
\hline & Pampatheriidae & & & & & & \\
\hline \multirow[t]{3}{*}{44} & Pampatherium & & & & $\mathrm{X}$ & & (71) \\
\hline & Rodentia & & & & & & \\
\hline & Castoridae & & & & & & \\
\hline 45 & Castoroides & & & & $\mathrm{X}$ & & (72) \\
\hline
\end{tabular}




\begin{tabular}{|c|c|c|c|c|c|c|}
\hline & Hydrochoeridae & & & & & \\
\hline 46 & Hydrochaeris & $\mathrm{X}$ & & & & (70) \\
\hline \multirow[t]{3}{*}{47} & Neochoerus & $\mathrm{X}$ & & & & (70) \\
\hline & Carnivora & & & & & \\
\hline & Ursidae & & & & & \\
\hline 48 & Arctodus & & & $\mathrm{X}$ & & (42) \\
\hline \multirow[t]{2}{*}{49} & Tremarctos & & & $\mathrm{X}$ & & (73) \\
\hline & Felidae & & & & & \\
\hline 50 & Homotherium & & $\mathrm{X}$ & & & (74) \\
\hline 51 & Miracinonyx & & & $\mathrm{X}$ & & (75) \\
\hline * & Panthera & & & $\mathrm{X}$ & & (42) \\
\hline \multirow[t]{3}{*}{52} & Smilodon $^{\mathrm{d}}$ & & & $\mathrm{X}$ & $?$ & (42) \\
\hline & Proboscidea & & & & & \\
\hline & Elephantidae & & & & & \\
\hline \multirow[t]{2}{*}{53} & Mammuthus ${ }^{\mathrm{d}}$ & & & $\mathrm{X}$ & $?$ & $(42)$ \\
\hline & Gomphotheriidae & & & & & \\
\hline \multirow[t]{2}{*}{54} & Cuvieronius & & $\mathrm{X}$ & & & (64) \\
\hline & Mammutidae & & & & & \\
\hline \multirow[t]{3}{*}{55} & Mammut & & & $\mathrm{X}$ & $?$ & $(42)$ \\
\hline & Perissodactyla & & & & & \\
\hline & Equidae & & & & & \\
\hline \multirow[t]{2}{*}{56} & Equus & & & $\mathrm{X}$ & & $(42)$ \\
\hline & Tapiridae & & & & & \\
\hline \multirow[t]{3}{*}{57} & Tapirus & & & $\mathrm{X}$ & & (76) \\
\hline & Artiodactyla & & & & & \\
\hline & Tayassuidae & & & & & \\
\hline 58 & Mylohyus & & & $\mathrm{X}$ & & $(42)$ \\
\hline \multirow[t]{2}{*}{59} & Platygonus & & & $\mathrm{X}$ & & $(42)$ \\
\hline & Camelidae & & & & & \\
\hline 60 & Camelops & & & $\mathrm{X}$ & & (42) \\
\hline 61 & Hemiauchenia & & & $\mathrm{X}$ & & $(42)$ \\
\hline \multirow[t]{2}{*}{62} & Paleolama & & & $\mathrm{X}$ & & (42) \\
\hline & Cervidae & & & & & \\
\hline 63 & Bretzia & $\mathrm{X}$ & & & & (70) \\
\hline 64 & Cervalces & & & $\mathrm{X}$ & & (42) \\
\hline 65 & Navahoceros & $\mathrm{X}$ & & & & (70) \\
\hline \multirow[t]{2}{*}{66} & Torontoceros & $\mathrm{X}$ & & & & (70) \\
\hline & Antilocapridae & & & & & \\
\hline 67 & Stockoceros & $\mathrm{x}$ & & & & (70) \\
\hline \multirow[t]{2}{*}{68} & Tetrameryx & $\mathrm{X}$ & & & & (70) \\
\hline & Bovidae & & & & & \\
\hline 69 & Bootherium & $\mathrm{X}$ & & & & (70) \\
\hline 70 & Euceratherium & & & & $\mathrm{X}$ & (42) \\
\hline \multirow[t]{5}{*}{71} & Saiga & $\mathrm{X}$ & & & & (70) \\
\hline & SOUTH AMERICA & & & & & \\
\hline & Mammalia & & & & & \\
\hline & Xenarthra & & & & & \\
\hline & Dasypodidae & & & & & \\
\hline 72 & Eutatus & & & & $\mathrm{x}$ & (77) \\
\hline \multirow[t]{2}{*}{73} & Propaopus & & & & $\mathrm{X}$ & (78) \\
\hline & Glyptodontidae & & & & & \\
\hline 74 & Chlamydotherium & & & & $\mathrm{X}$ & (79) \\
\hline
\end{tabular}




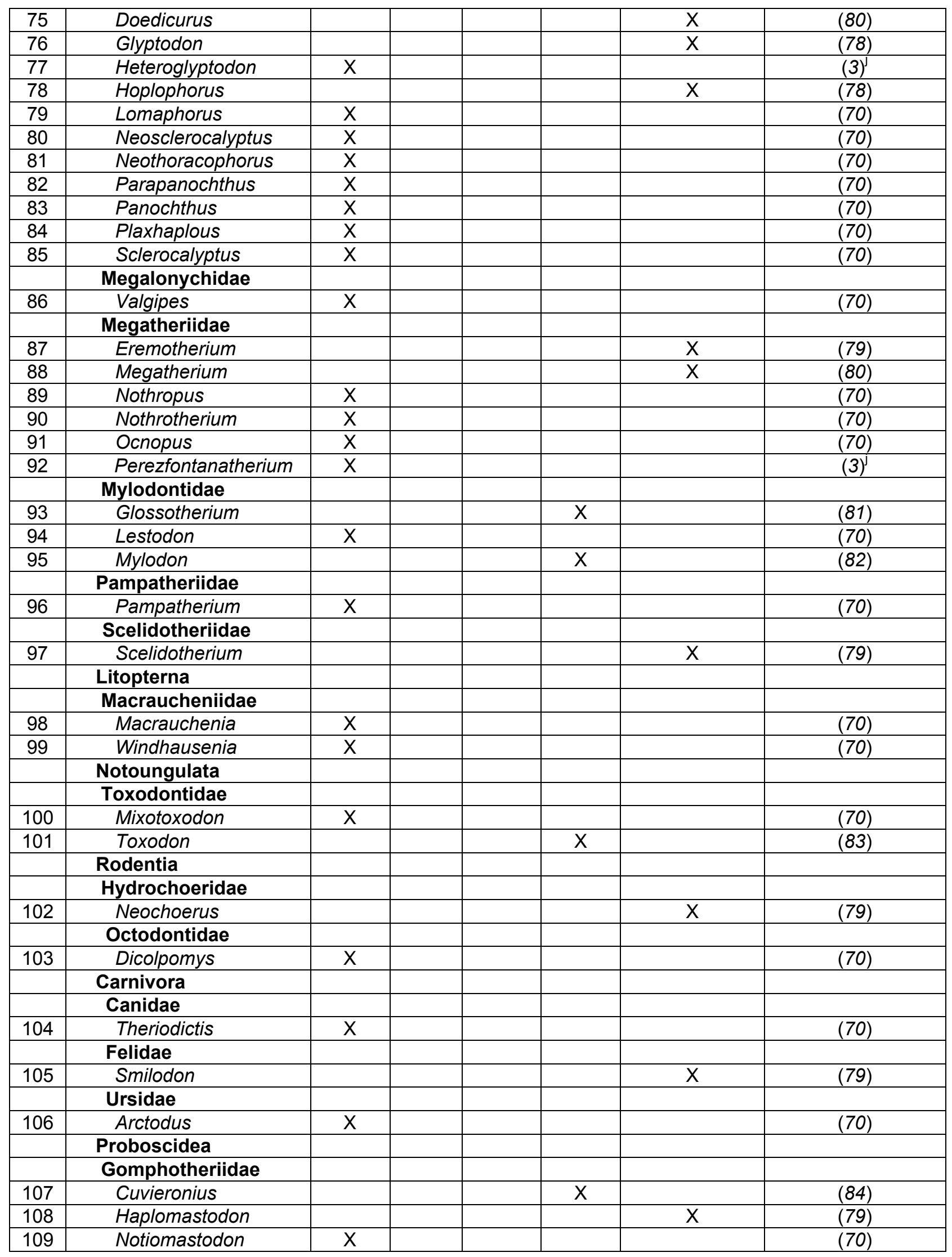




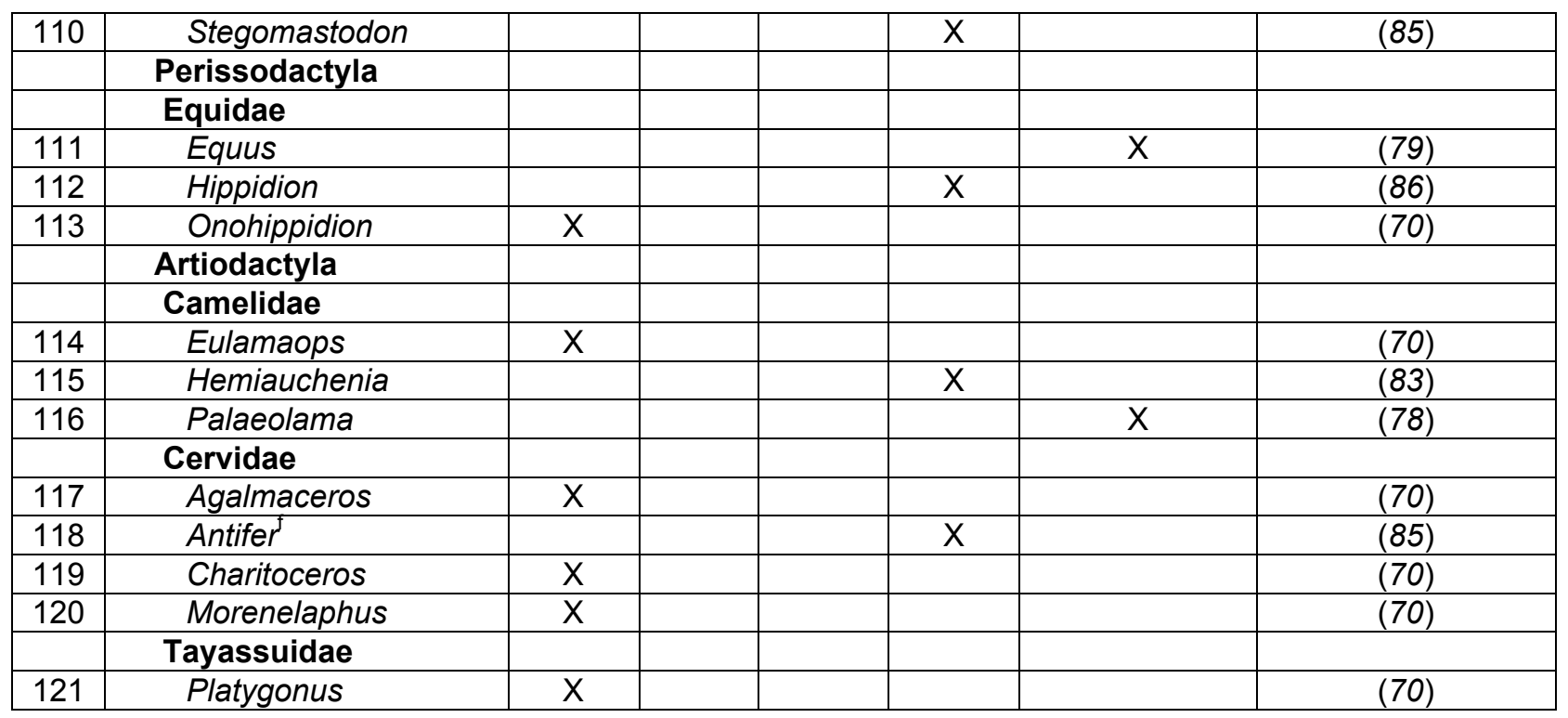

* Historic reports, not counted in totals.

? Questionable occurrence, not counted in totals.

${ }^{a}$ Megaloceros of ref. (66).

${ }^{\mathrm{b}}$ Ref. (29) reports a disarticulated Diprotodon sp. from the Holocene.

${ }^{\mathrm{c}}$ North America north of Mexico

${ }^{d}$ Grade 7 dates reported for the Holocene. Grade 8 and 9 dates imply extinction between 13-10 ka. Grades based on the radiocarbon grading scale of ref. (87). This scale rates the type of material dated (on a scale of 1-6) and the strength of association (on a scale of 1-3) between the dated material and the fauna within the deposit-the rating for the type of material dated and the strength of association are added together. Wood, charcoal, and amino acids are given a rating of 5 or 6 , while shell, terrestrial carbonate, and whole bone are given a score of 1 or 2 , for example. A strong association is given a score of 3 , medium association is given a 2 , and weak association is given a 3 . A genus that had amino acids dated will receive a grade of 9 [Type of material (grade 6) + association strong (grade 3)]. Refs. (87-89) argue that dates with a grade of 8 or 9 are "good dates" and are the only dates that should be used in analyses of the chronology of the late Pleistocene extinction.

${ }^{\mathrm{e}}$ It is difficult to assign radiocarbon grades (see footnote d) for many of the dates presented in the literature; however, based on the type of material dated very few, if any, of the South American dates reported in the literature would receive a grade of 8 or 9 as defined in ref. (87). The South American dates, especially for purported Holocene megafaunal extinctions, need detailed evaluation before they can be considered robust.

${ }^{f}$ Paraceros of ref. (70).

g 100,000-10,000 years ago in Africa, Eurasia, and North America. Late Pleistocene of Australia. Lujanian Land Mammal Age of South America.

$\mathrm{h}<10,000$ radiocarbon years.

' We utilized review articles and do not cite other articles that give similar dates for the respective taxa; those citations are available in the review articles listed in our References and Notes section.

${ }^{j}$ Ref. (3) cites ref. (90) as the source for this genus occurring in the Lujanian of South America. 
Table S2. Summary of simulations designed to test the overkill model. "\# of prey" refers to how many species of prey the simulation involved, and "Coupled Dynamics" refers to whether changes human population numbers are linked to changes in prey density (yes) or fixed (no).

\begin{tabular}{|c|c|c|c|}
\hline Study by: & \#. of prey & $\begin{array}{c}\text { Coupled } \\
\text { Dynamics? }\end{array}$ & Do the results support overkill? \\
\hline $\begin{array}{l}\text { Budyko (91): evaluates impact of } \\
\text { human population growth on } \\
\text { Eurasian mammoths }\end{array}$ & $1^{*}$ & $\begin{array}{l}\text { Yes, with } \\
\text { exponential human } \\
\text { population growth }\end{array}$ & $\begin{array}{l}\text { Yes, but exponential } \\
\text { population growth makes } \\
\text { extinction inevitable. }\end{array}$ \\
\hline $\begin{array}{l}\text { Mosiman \& Martin (5): studies } \\
\text { first entry of Clovis hunters into } \\
\text { conterminous USA }\end{array}$ & 1 * & $\begin{array}{l}\text { Yes, with logistic } \\
\text { human population } \\
\text { growth and a fixed } \\
\text { carrying capacity }\end{array}$ & $\begin{array}{l}\text { Yes, with blitzkrieg under } \\
\text { certain assumptions. Model } \\
\text { fails stability tests so } \\
\text { extinction inevitable under } \\
\text { most conditions. }\end{array}$ \\
\hline $\begin{array}{l}\text { Whittington \& Dyke (4): a } \\
\text { sensitivity test of Mosiman \& } \\
\text { Martin (5) model under a wide } \\
\text { range of parameter values }\end{array}$ & $1^{*}$ & $\begin{array}{l}\text { Yes, with logistic } \\
\text { human population } \\
\text { growth and a fixed } \\
\text { carrying capacity }\end{array}$ & $\begin{array}{l}\text { Yes, with blitzkrieg under } \\
\text { limited conditions and gradual } \\
\text { overkill under a wide set } \\
\text { assumptions. Model fails } \\
\text { stability tests so extinction } \\
\text { inevitable under most } \\
\text { scenarios. }\end{array}$ \\
\hline $\begin{array}{l}\text { Belovsky (92): an optimal- } \\
\text { foraging model for North America } \\
\text { with sophisticated treatments of } \\
\text { environmental controls on } \\
\text { primary production, animal } \\
\text { digestion, energetics, and } \\
\text { foraging }\end{array}$ & $\begin{array}{c}2 \\
\text { hunted vs. } \\
\text { gathered } \\
\text { food }\end{array}$ & $\begin{array}{l}\text { Yes, with human } \\
\text { population growth } \\
\text { determined by an } \\
\text { energetic model }\end{array}$ & $\begin{array}{l}\text { No. Assumes a relatively high } \\
r \text { for prey that may reduce } \\
\text { extinctions. Predicts } \\
\text { megafaunal extinction in } \\
\text { areas of high available } \\
\text { primary production, because } \\
\text { human population growth is } \\
\text { subsidized by gathered food. } \\
\text { Megafauna survive in areas of } \\
\text { low production (i.e., tundra, } \\
\text { forest). Yields general result } \\
\text { that extinction results not from } \\
\text { megafaunal specialization but } \\
\text { rather from population growth } \\
\text { of omnivores. }\end{array}$ \\
\hline $\begin{array}{l}\text { Winterhalder et al. (93) optimal } \\
\text { foraging model of population } \\
\text { dynamics of hunter-gatherers } \\
\text { and prey (varied reproductive } \\
\text { and nutrient traits); not "place- } \\
\text { based" }\end{array}$ & 1 to 2 & $\begin{array}{l}\text { Yes, with human } \\
\text { population growth } \\
\text { determined by an } \\
\text { energetic model }\end{array}$ & $\begin{array}{l}\text { No. Human populations } \\
\text { stabilize or crash after wild } \\
\text { oscillations if too much time is } \\
\text { spent hunting. Prey persist in } \\
\text { either scenario. Yields } \\
\text { general result that predators } \\
\text { in very simple systems are } \\
\text { unlikely to drive prey to } \\
\text { extinction; the reverse is more } \\
\text { likely. }\end{array}$ \\
\hline $\begin{array}{l}\text { Anderson (94): models moa } \\
\text { predation in New Zealand }\end{array}$ & $1^{*}$ & $\begin{array}{l}\text { No, exponential } \\
\text { growth at plausible } \\
\text { rate }\end{array}$ & $\begin{array}{l}\text { Yes, for blitzkrieg, but claims } \\
\text { there are too few moa } \\
\text { remains. No consideration of } \\
\text { taphonomic impacts on this } \\
\text { claim. }\end{array}$ \\
\hline
\end{tabular}




\begin{tabular}{llll}
\hline $\begin{array}{l}\text { Winteralder \& Lu (95): optimal } \\
\text { foraging model of population }\end{array}$ & Up to 4 & $\begin{array}{l}\text { Yes, with human } \\
\text { growth determined } \\
\text { dynamics of hunter-gatherers }\end{array}$ & $\begin{array}{l}\text { Overkill in many cases for } \\
\text { slow-breeding taxa, }\end{array}$ \\
$\begin{array}{l}\text { and prey (varied reproductive } \\
\text { and nutrient traits); not "place- }\end{array}$ & & & $\begin{array}{l}\text { particularly if subsidized by a } \\
\text { fast-breeding species. Slow } \\
\text { based" but results used to }\end{array}$ \\
breeders are not vulnerable to \\
large game specialists.
\end{tabular}

discuss conservation in

Amazonia and Pleistocene

overkill

Choquenot \& Bowman (96): $\quad 1^{*} \quad$ No, varied human $\quad$ Mostly no. Varied hunting

models Aboriginal impacts in a

densities efficiency and human

hypothetical tract of north

densities. Counter-intuitively

Australian Eucalyptus savanna

on single prey (varied

reproductive traits)

found smaller megafauna

would have been more readily

exterminated than larger

megafauna, a result dictated

by using relatively low human

densities and typical levels of

hunting efficiency. Overkill

would require higher human

densities.

\begin{tabular}{lll}
\hline $\begin{array}{l}\text { Holdaway \& Jacomb (97): } \\
\text { models moa predation in New }\end{array}$ & $1^{*}$ & $\begin{array}{l}\text { No, exponential } \\
\text { growth at plausible } \\
\text { Zealand }\end{array}$ \\
& rate
\end{tabular}

Yes, consistent with blitzkrieg,

predicts extinction of 11

species of moas in $<100$ years.

Alroy (11): focused on first entry $41 \quad$ Yes

Overkill under many

of Clovis hunters into

conditions; slightly too slow

conterminous USA

for blitzkrieg sensu stricto but

still less than 1000 years to

extinction of most species.

Correctly predicts fates of $\sim 73 \%$ of the species.

\begin{tabular}{|c|c|c|c|}
\hline $\begin{array}{l}\text { Brook \& Bowman (16): } \\
\text { evaluation of some aspects of } \\
\text { Alroy simulation (11) with a } \\
\text { focus on understanding effects of } \\
\text { prey naiveté }\end{array}$ & $1^{*}$ & $\begin{array}{l}\text { No, varied human } \\
\text { densities }\end{array}$ & $\begin{array}{l}\text { Mostly no. Results are } \\
\text { dependent on assumptions } \\
\text { about prey naiveté / human } \\
\text { hunting efficiency. Not directly } \\
\text { comparable to ref (11) } \\
\text { because it used lower human } \\
\text { densities and simulated } \\
\text { predation on a single prey. }\end{array}$ \\
\hline $\begin{array}{l}\text { Brook \& Bowman (17): sensitivity } \\
\text { analysis of the model used in ref } \\
16, \text { and comparison of results to } \\
\text { size selectivity of extinction at a } \\
\text { global level. Varied prey and } \\
\text { human population dynamics, } \\
\text { prey naiveté, hunting success, } \\
\text { and habitat quality }\end{array}$ & $1^{*}$ & $\begin{array}{l}\text { No, logistic growth } \\
\text { to equilbrium } \\
\text { density }\end{array}$ & $\begin{array}{l}\text { Yes. Overkill under many } \\
\text { combinations of parameters, } \\
\text { with a best fit to body size } \\
\text { data for moderate levels of } \\
\text { predation, some loss of } \\
\text { naivete, and moderate } \\
\text { declines in habitat quality. } \\
\text { Median time to extinction } \\
\text { between } 700 \text { and } 800 \text { years. }\end{array}$ \\
\hline
\end{tabular}

"While these models treat only 1 prey explicitly, they implicitly assume that humans switch to secondary food sources when this prey become locally extinct. 
Table S3. Clovis-age archaeological occurrences, kill-sites, and late-glacial (15.5-9.5 ky RCBP) paleontological occurrences of some extinct megafauna documented in the FAUNMAP database (74).

\begin{tabular}{|c|c|c|c|c|c|c|c|c|}
\hline Taxon & $\begin{array}{l}A^{a} \\
\text { Kill }\end{array}$ & $\begin{array}{c}\mathrm{B}^{\mathrm{b}} \\
\text { Arch. }\end{array}$ & $\begin{array}{c}C^{C} \\
\text { FAUN. } \\
\text { All }\end{array}$ & $\begin{array}{c}\mathrm{D}^{\mathrm{d}} \\
\text { FAUN. } \\
\text { LG }\end{array}$ & $\begin{array}{c}A: C^{e} \\
P\end{array}$ & $\begin{array}{c}A: D^{f} \\
P\end{array}$ & $\begin{array}{c}B: C^{e} \\
P\end{array}$ & $\begin{array}{c}B: D^{f} \\
P\end{array}$ \\
\hline Arctodus & 0 & 1 & 37 & 8 & 0.25 & $0.63[0.15]$ & 0.41 & $0.86[0.20]$ \\
\hline Camelops & 1 & 10 & 139 & 15 & 0.09 & $0.50[0.17]$ & 0.72 & $0.0004[0.46]$ \\
\hline Capromeryx & 0 & 3 & 25 & 1 & 0.35 & $0.86[0.61]$ & 0.31 & $0.0001[0.08]$ \\
\hline Equus & 2 & 13 & 440 & 17 & 0.04 & $0.15[0.30]$ & 0.03 & $<0.0001[0.30]$ \\
\hline Glossotherium & 0 & 1 & 48 & 8 & 0.19 & 0.63 [0.15] & 0.27 & $0.86[0.20]$ \\
\hline Hemiauchenia & 0 & 3 & 54 & 5 & 0.17 & 0.70 [0.25] & 0.86 & $0.02[0.75]$ \\
\hline Pampitherium & 0 & 1 & 22 & 3 & 0.38 & 0.77 [0.37] & 0.76 & $0.31[0.78]$ \\
\hline Mammut & 2 & 7 & 211 & 68 & 0.07 & [0.001] & 0.15 & [0.001] \\
\hline Mammuthus & 12 & 21 & 337 & 45 & & 0.001 & & 0.001 \\
\hline Megalonyx & 0 & 1 & 53 & 4 & 0.17 & $0.73[0.31]$ & 0.22 & 0.44 [0.58] \\
\hline Platygonus & 0 & 4 & 88 & 16 & 0.08 & $0.49[0.05]$ & 0.57 & 0.19 [0.31] \\
\hline Smilodon & 0 & 1 & 35 & 3 & 0.27 & $0.77[0.37]$ & 0.44 & $0.31[0.78]$ \\
\hline Tapirus & 0 & 1 & 56 & 6 & 0.16 & $0.67[0.21]$ & 0.20 & 0.67 [0.33] \\
\hline
\end{tabular}

${ }^{a}$ Sites with robust evidence for human predation (33)

${ }^{\mathrm{b}}$ Sites with minimally acceptable evidence for association between Clovis-age people and extinct megafauna (33)

${ }^{c}$ All sites in the FAUNMAP database (33) in which the genus is reported, from 40 ky RCBP through Holocene age assignment in the database.

${ }^{d}$ All late-glacial (LG) age (15.5-9.5 ky RCBP) sites with the genus contained in the on-line FAUNMAP database (http://museum.state.il.us/research/faunmap), except Tapirus, which is from reference (41).

${ }^{\mathrm{e}}$ Chi-square probability that the indicated ratio for the genus is the same as the respective ratio for Mammuthus; bold indicates significantly more archaeological association than expected relative to the reference genus, italics indicate less archaeological association than expected.

${ }^{f}$ Chi-square probability that the indicated ratio for the genus is the same as the respective ratio for Mammut or [Mammuthus]; bold indicates significantly more archaeological association than expected relative to the reference genus, italics indicate less archaeological association than expected. 


\section{References and Notes}

1. S. K. Lyons, F. A. Smith, J. H. Brown, Evolutionary Ecology Research 6, 339 (2004).

2. J. Alroy, in Extinctions in near time: causes, contexts, and consequences R. D. E. MacPhee, Ed. (Kluwer Academic/Plenum Publishers, New York, 1999) pp. 105-143.

3. M. C. McKenna, S. K. Bell, Classification of mammals above the species level (Columbia University Press, New York, 1997).

4. S. L. Whittington, B. Dyke, in Quaternary extinctions: a prehistoric revolution P. S. Martin, R. G. Klein, Eds. (University of Arizona Press, Tucson, 1984) pp. 451-465.

5. J. E. Mosimann, P. S. Martin, American Scientist 63, 304 (1975).

6. $\quad$ E. A. Smith, M. Wishnie, Annual Review of Anthropology 29, 493-524 (2000).

7. J. M. Diamond, Journal of Archaeological Science 16, 167 (1989).

8. A. P. Kershaw, in Quaternary extinctions: a prehistoric revolution P. S. Martin, R. G. Klein, Eds. (University of Arizona Press, Tucson, 1984) pp. 691-707.

$9 . \quad$ G. H. Miller et al., Science 283, 305 (1999).

10. P. Murray, P. Vickers-Rich, Magnificent Mihirungs: The Colossal Flightless Birds of the Australian Dreamtime. (University of Indiana Press., Bloomington, Indiana, 2004).

11. J. Alroy, Science 292, 1893 (2001).

12. R. Slaughter, J. Skulan, Science 294, 1460 (2001).

13. J. Alroy, Science 293, 2205 (2001).

14. J. Alroy, Science 294, 1459 (2001).

15. D. K. Grayson, Science 294, 1459 (2001).

16. B. W. Brook, D. M. J. S. Bowman, Proceedings of the National Academy of Sciences of the United States of America 99, 14624 (2002).

17. B. W. Brook, D. M. J. S. Bowman, Journal of Biogeography 31, 517 (2004).

18. R. D. E. MacPhee et al., Journal of Archaeological Science 29, 1017 (2002).

19. R. D. Guthrie, Nature 429, 746 (2004).

20. S. L. Vartanyan, V. E. Garutt, A. V. Sher, Nature 362, 337 (25 March, 1993).

21. C. N. Johnson, Proceedings of the Royal Society of London Series B, Biological Sciences 269, 2221 (2002).

22. A. J. Stuart, in Extinctions in near time: causes, contexts, and consequences R. D. E. MacPhee, Ed. (Kluwer Academic/Plenum Publishers, New York, 1999) pp. 257-270.

23. R. D. Guthrie, Nature 426, 169 (2003).

24. A. J. Stuart, L. D. Sulerzhitsky, L. A. Orlova, Y. V. Kuzmin, A. M. Lister, Quaternary Science Reviews 21, 1559 (2002).

25. A. D. Barnosky, Quaternary Research 25, 128 (1986).

26. S. Gonzalez, A. C. Kitchener, A. M. Lister, Nature 405, 753 (2000).

27. A. D. Barnosky, Science 228, 340 (1985).

28. I. Barnes, P. Matheus, B. Shapiro, D. Jensen, A. Cooper, Science 295, 2267 (2002).

29. R. G. Roberts et al., Science 292, 1888 ().

30. S. Wroe, J. Field, R. Fullagar, L. S. Jermin, Alcheringa 28, 291 (2004).

31. P. S. Martin, R. G. Klein, Eds., Quaternary extinctions: a prehistoric revolution (University of Arizona Press, Tucson, 1984).

32. J. Peters, A. Gautier, J. S. Brink, W. Haenen, Journal of Archaeological Science 21, 17 (1994).

33. D. K. Grayson, D. J. Meltzer, Journal of World Prehistory 16, 313 (2002).

34. D. K. Grayson, D. J. Meltzer, Journal of Archaeological Science 30, 585 (2003).

35. G. Haynes, The Early Settlement of North America: The Clovis Era (Cambridge University Press, Cambridge, 2002).

36. D. J. Mulvaney, J. Kamminga, Prehistory of Australia (Smithsonian Institution Press, Washington, D. C., 1999).

37. J. Field, J. R. Dodson, Proceedings of the Prehistoric Society 65, 275 (1999).

38. D. J. Meltzer et al., American Antiquity 62, 659 (1997).

39. S. J. Fiedel, G. Haynes, Journal of Archaeological Science 31, 121 (2004).

40. T. D. Dillehay, The settlement of the Americas: a new prehistory (Basic Books, New York, 2000).

41. FAUNMAP Working Group, Illinois Museum Scientific Papers 25, 1 (1994). 
42. A. J. Stuart, Biological Reviews 66, 453 (1991).

43. K. C. Moriarty, M. T. McCulloch, R. T. Wells, M. C. McDowell, Palaeogeography, Palaeoclimatology, Palaeoecology 159, 113 (2000).

44. A. D. Barnosky, Ed., Biodiversity response to climate change in the Middle Pleistocene: the Porcupine Cave fauna from Colorado (University of California Press, Berkeley, 2004).

45. A. D. Barnosky, in Mass extinctions: processes and evidence S. K. Donovan, Ed. (Belhaven Press, London, 1989) pp. 235-254.

46. P. U. Clark, R. B. Alley, D. Pollard, Science 286, 1104 (1999).

47. J. Kutzbach et al., Quaternary Science Reviews 17, 473 (1998).

48. W. Dansgaard et al., Nature 364, 218 (1993).

49. M. E. Raymo, K. Ganley, S. Carter, D. W. Oppo, J. McManus, Nature 392, 699 (1998).

50. J. R. Petit et al., Nature 399, 429 (1999).

51. D. T. Rodbell, Science 290, 285 (2000).

52. T. R. Karl, K. E. Trenberth, Science 302, 1719 (2003).

53. A. D. Barnosky, E. A. Hadly, C. J. Bell, Journal of Mammalogy 84, 354 (2003).

54. C. D. Thomas et al., Nature 427, 145 (2004).

55. P. Niemelä, F. S. Chapin, III, K. Danell, J. P. Bryant, Climatic Change 48, 427 (2001).

56. G.-R. Walther et al., Nature 416, 389 (28 March, 2002).

57. J. O. Ogutu, N. Owen-Smith, Ecology Letters 6, 412 (2003).

58. B. R. Patterson, V. A. Power, Oecologia (Berlin) 130, 62 (2002).

59. E. Post, M. C. Forchhammer, Nature 420, 168 (2002).

60. R. W. Graham, E. C. Grimm, Trends in Ecology and Evolution 5, 289 (1990).

61. FAUNMAP Working Group, Science 272, 1601 (1996).

62. A. D. Barnosky et al., Proceedings of the National Academy of Sciences USA 101, 9297 (2004).

63. N. Owen-Smith, Paleobiology 13, 351 (1987).

64. P. L. Koch, K. A. Hoppe, S. D. Webb, Chemical Geology 152, 119 (1998).

65. P. L. Koch, N. S. Diffenbaugh, K. A. Hoppe, Palaeogeography, Palaeoclimatology, Palaeoecology 207, 331 (2004).

66. P. S. Martin, in Quaternary extinctions, a prehistoric revolution P. S. Martin, R. G. Klein, Eds. (The University of Arizona Press, Tucson, Arizona, 1984) pp. 354-403.

67. J. A. Lee-Thorp, P. B. Beaumont, Quaternary Research, 426 (1995).

68. R. G. Klein, Journal of Archaeological Science 21, 725 (1994).

69. T. F. Flannery, R. G. Roberts, in Extinctions in near time: causes, contexts, and consequences R. D. E. MacPhee, Ed. (Kluwer Academic/Plenum Publishers, New York, 1999) pp. 239-255.

70. P. S. Martin, D. W. Steadman, in Extinctions in near time: causes, contexts, and consequences R. D. E. MacPhee, Ed. (Kluwer Academic/Plenum Publishers, New York, 1999) pp. 17-55.

71. E. Johnson, Ed., Lubbock Lake: Late Quaternary studies on the southern high plains (Texas A\&M Press, College Station, 1987).

72. D. W. Steadman, T. W. T. W. Stafford Jr., R. E. Funk, Quaternary Research 47, 105 (1997).

73. S. D. Emslie, G. S. Morgan, in Late Quaternary Environments and Deep History: A tribute to Paul Martin D. W. Steadman, J. I. Mead, Eds. (The Mammoth Site of Hot Springs, South Dakota, Inc., Hot Springs, South Dakota, 1995.), vol. Scientific papers, Volume 3, pp. 65-83.

74. FAUNMAP Working Group, http://www. museum.state.il.us/research/faunmap/ (2003).

75. S. D. Emslie, Journal of Paleontology 60, 170 (1986).

76. M. W. Beck, Paleobiology 22, 91 (1996).

77. S. F. Vizcaíno, N. Milne, M. S. Bargo, Ameghiniana 40, 89 (2003).

78. M. Faure, C. Guerin, and F. Parenti. 1999., Comptes Rendus de l'Académie des Sciences, Série II, Sciences de la Terre et des Planètes 329, 443 (1999).

79. G. Ficcarelli et al., Journal of South American Earth Sciences 15, 835 (2003).

80. L. A. Borrero, M. Zarate, L. L. Miotti, M. Massone, Quaternary International 49-50, 191 (1998).

81. M. Coltorti et al., Journal of South American Earth Sciences 11, 581 (1998).

82. L. A. Borrero, Quaternary International 109-110, 87 (2003).

83. G. A. Martinez, Antiquity 75, 523 (September, 2001).

84. T. D. Dillehay, M. B. Collins, American Antiquity 56, 333 (1991).

85. L. Nuñez et al., Revista Chilena de Historia Natural 67, 503 (1994).

86. M. T. Alberdi, L. Miotti, J. L. Prado, Journal of Archaeological Science 28, 411 (2001). 
87. J. I. Mead, D. J. Meltzer, in Quaternary extinctions: a prehistoric revolution P. S. Martin, R. G. Klein, Eds. (University of Arizona Press, Tucson, 1984) pp. 440-450.

88. D. K. Grayson, Journal of Archaeological Science 16, 153 (1989).

89. D. K. Grayson, Journal of World Prehistory 5, 193 (1991).

90. F. L. Roselli, Contribucion al estudio de la geo paleontologia; Departamentos de Colonia y Soriano (Republica Oriental del Uruguay) [Contribution to the study of geopaleontology; Colonia and Soriano] (Uruguay Biblioteca Soc. Ciencias Naturales "Kraglievich-Fontana", Nueva Palmira, (URY), 1976).

91. M. I. Budyko, Soviet Geography Review and Translations 8, 783 (1967).

92. G. E. Belovsky, Journal of Anthropological Archaeology 7, 329 (1988).

93. B. Winterhalder, W. Baillargeon, F. Cappelletto, I. R. Daniel, Jr, C. Prescott, Journal of Anthropological Archaeology 7, 289 (1988).

94. A. Anderson, Journal of Archaeological Science 16, 137 (1989).

95. B. Winterhalder, F. Lu, Conservation Biology 11, 1354 (1997).

96. D. Choquenot, D. M. J. S. Bowman, Global Ecology and Biogeography Letters 7, 167 (1998).

97. R. N. Holdaway, C. Jacomb, Science 287, 2250 (2000). 